Marine Biology

December 2008, Volume 156, Number 2 : Pages

155-169

http://dx.doi.org/10.1007/s00227-008-1072-2

(c) 2008 Springer. Part of Springer Science+Business

Media

The original publication is available at http://www.springerlink.com
Archimer, archive institutionnelle de l'Ifremer http://www.ifremer.fr/docelec/

\title{
Sterol production and phytosterol bioconversion in two species of heterotrophic protists, Oxyrrhis marina and Gyrodinium dominans
}

\author{
Fu-Lin Evelyn Chu ${ }^{1,}{ }^{*}$, Eric D. Lund ${ }^{1}$, Paul R. Littreal ${ }^{1}$, Kate E. Ruck ${ }^{1}$, Ellen Harvey ${ }^{1}$, Jean-René Le \\ $\mathrm{Coz}^{2}$, Yanic Marty ${ }^{3}$, Jeanne Moal ${ }^{2}$ and Philippe Soudant ${ }^{4}$
}

\footnotetext{
${ }^{1}$ Virginia Institute of Marine Science, College of William \& Mary, Gloucester Point, VA 23062, USA

2 IFREMER, BP 70, 29280 Plouzané, France

${ }^{3}$ Université de Bretagne Occidentale, UMR/CNRS 6521, CS 93837, 29238 Brest Cedex 3, France

${ }^{4}$ Institut Universitaire Européen de la Mer, Université de Bretagne Occidentale, 29280 Plouzané, France

*: Corresponding author : Fu-Lin Evelyn Chu, email address : chu@vims.edu
}

\begin{abstract}
:
The kinetics and efficiency of sterol production and bioconversion of phytosterols in two heterotrophic protists Oxyrrhis marina and Gyrodinium dominans were examined by feeding them two different algal species (Rhodomonas salina and Dunaliella tertiolecta) differing in sterol profiles. $R$. salina contains predominantly brassicasterol $(\cong 99 \%)$ and $<2 \%$ cholesterol. The major sterols in $D$. tertiolecta are ergosterol (45-49\%), 7-dehydroporiferasterol (29-31\%) and fungisterol (21-26\%). O. marina fed $R$. salina metabolized dietary brassicasterol to produce 22-dehydrocholesterol and cholesterol. O. marina fed $D$. tertiolecta metabolized dietary sterols to produce cholesterol, 22-dehydrocholesterol, brassicasterol and stigmasterol. G. dominans fed either $R$. salina or $D$. tertiolecta metabolized dietary sterols to make cholesterol, brassicasterol and a series of unknown sterols. When protists were fed $R$. salina, which contains cholesterol, the levels of cholesterol were increased to a magnitude of nearly 5to 30-fold at the phytoplankton-heterotrophic protist interface, equivalent to a production of $172.5 \pm 16.2$ and $987.7 \pm 377.7 \mathrm{ng}$ cholesterol per $\mathrm{mg} R$. salina carbon consumed by $O$. marina and $G$. dominans, respectively. When protists were fed $D$. tertiolecta, which contains no cholesterol, a net production of cholesterol by the protists ranged from $123.2 \pm 30.6$ to $871.8 \pm 130.8 \mathrm{ng}$ per $\mathrm{mg}$ algal C consumed. Cholesterol is not only the dominant sterol, but a critical precursor for many physiologically functional biochemicals in higher animal. As intermediates, these heterotrophic protists increase the amount of cholesterol at the phytoplankton-zooplankton interface available to higher trophic levels relative to zooplankton feeding on algae directly.
\end{abstract}




\section{INTRODUCTION}

Microzooplankton, dominated by ciliates and heterotrophic dinoflagellates, hold an important position in both freshwater and marine food webs because of their nutritional and energetic contributions to consumers at higher trophic levels. Unlike heterotrophic protists, which are a significant food source to crustacean zooplankton in nature, pico-plankton and nanoplankton less than $10 \mu \mathrm{m}$ usually cannot be directly consumed by some mesozooplankton such as calanoid copepods (Ohman and Runge 1994, Merrell and Stoecker 1998, Bollens and Penry 2003, Gifford et al 2007). Heterotrophic protists are important grazers of autotrophic phytoplankton of various sizes (pico-, nano- and micro-algae) and themselves are prey for metazoans such as copepods and daphnids. Thus, they provide a critical link for channeling energy and nutrients from the base of the pelagic food web, via the microbial loop, to higher trophic levels. As intermediates, some heterotrophic protists not only assimilate/repackage nutrients from nano-and pico-plankton for subsequent use by zooplankton grazers and enhance the carbon transfer efficiency at the phytoplankton-zooplankton interface, but upgrade the biochemical constituents of their algal food for subsequent use at higher trophic levels by producing essential lipids that are absent in their algal diets (Klein Breteler et al. 1999; Bec et al. 2003; Broglio et al. 2003; Tang and Taal 2005;Veloza et al. 2006; Bec et al. 2006; Chu et al. 2008).

Some essential lipids such as the long chain polyunsaturated fatty acids, eicosapentaenoic acid (EPA), docosahexaenoic acid (DHA) and arachidonic acid (AA), and sterols (Gurr et al. 2002) are not only major constituents of structural lipids, but are precursors of physiologically 
active metabolites that are involved in many biological and biochemical processes. In aquatic food webs, phytoplankton is the primary producer of these essential components. On the other hand, crustaceans, including copepods and higher consumers, are incapable of synthesizing some of these essential components and thus rely on dietary sources for these compounds. Trophic upgrading of food deficient in essential lipids by heterotrophic protists has been documented in both marine (e.g., Klein Breteler et al. 1999; Tang and Taal 2005; Broglio et al. 2003; Veloza et al. 2006; Chu et al. 2008) and freshwater ecosystems (Bec et al. 2003; Boechat and Adrian 2005; Martin-Creuzburg et al. 2005a; Bec et al. 2006). While studies of "trophic upgrading” in freshwater ecosystems emphasize sterol production and dietary sterol modification as being important (Bec et al. 2006), in marine ecosystems it has been most strongly linked to long chain n-3 essential fatty acid production (Chu et al. 2008; Lund et al. 2008). The long chain n-3 essential fatty acid (LCn-3EFA) production by two marine heterotrophic protists, Oxyrrhis marina and Gyrodinium dominans, fed an alga (Dunaliella tertiolecta) deficient of the LCn3EFAs, EPA and DHA have been recently quantified (Chu et al. 2008). The contribution, particularly of DHA, by these two heterotrophic protists to the pelagic food webs appears to be quantitatively and ecologically significant and comparable to or higher than three representative species of algae (Chaetoceros calcitrans, Tetraselmis suecica, and Rhodomonas salina) that also contain LCn-3EFAs.

However, sterols are vital components of all eukaryotes (Volkman 2003) and generally account for $\sim 0.1 \%$ of wet weight (Ackman 1989). Sterols are involved in a wide range of physiological functions and are critical for growth and reproduction (Finkelstein and Cass 1967; Bruckdorfer et al. 1969; Demel et al. 1972; Ederington et al. 1995; Crockett 1998). The essential 
nature of sterols to the functioning of biological membranes makes them an important dietary component for organisms, such as calanoid copepods and Daphnia (Klein Breteler et al. 1999; Bec et al. 2006; Martin-Creuzburg et al. 2005b, 2008) that lack the ability to synthesize them de novo (Ballantine et al. 1980; Goad et al. 1983; Kanazawa 2001). Copepods are by far the most abundant animal group of marine plankton on which the ocean food chain depends. They hold the key for upward carbon and nutrient transfer since they are the main consumers of auto-and hetero-trophic protists. Along with LCn-3EFAs, dietary sterol content and composition could be potential limiting factors for egg production in copepods (Hasset 2004). It has been demonstrated that not only sterol content, but also sterol composition are critical in supporting the growth and reproduction of the freshwater dominant herbivores, the genus Daphnia (Von Elert et al. 2003, Martin-Creuzburg and Von Elert 2004, Martin-Creuzburg et al. 2005a; 2005b; Bec et al. 2006).

The ability of herbivorous heterotrophic protists to synthesize or modify sterols may be critical in determining copepod nutrition. Copepod survivorship, fecundity and offspring's survival are all adversely affected by diets low or deficient in LCn-3 EFAs and sterols (Klein Breteler et al. 1999, 2004, 2005; Broglio et al. 2003; Tang and Taal 2005; Veloza et al. 2006). Moreover, the nutritional quality, such as the LCn-3 EFAs and sterol content of the copepods, is an important factor controlling the development and growth and recruitment of fish (St. John and Lund 1996; St. John et al. 2001). To our knowledge, there are only three studies suggesting that marine heterotrophic protists can synthesize sterols from sterol-deficient diets (Harvey et al. 1997; Klein Breteler et al. 1999; Adolf et al. 2007). Although the heterotrophic protist Oxyrrhis marina has been shown to synthesize sterols and/or modify those present in its algal diet (Klein Breteler et al. 1999, 2005), its efficiency in sterol production and the ecological significance of 
the production have not been quantified. Additionally, there may be species-specific differences in sterol production and dietary sterol modification among heterotrophic protists. To assess the sterol production and bioconversion of phytosterols by heterotrophic protists and their quantitative and potential ecological significance, we first examined the kinetics, efficiency and quantity of sterol production of two heterotrophic protists, Oxyrrhis marina and Gyrodinium dominans, fed two different algal species differing in sterol profiles.

\section{MATERIALS AND METHODS}

\section{Algal and protist cultures}

The chlorophyte Dunaliella tertiolecta (CCMP 1320) and the cryptophyte, Rhodomonas salina (CCMP 1319) were obtained from Provasoli-Guillard National Center for Culture of Marine Phytoplankton (CCMP) and cultured in f/2 culture medium prepared from artificial sea water (ASW) of salinity 20. R. salina and D. tertiolecta, which differ in sterol profiles (Goad et al. 1983; Patterson et al. 1992; Zelazny et al. 1995; Klein Breteler et al. 1999), were used as the prey for feeding experiments with the heterotrophic protists, Oxyrrhis marina and Gyrodinium

dominans. Both R. salina and D. tertiolecta cultures used in feeding experiments were grown in 1-L round bottom flasks with aeration in a walk in environmental room at $19{ }^{\circ} \mathrm{C}$ with a $12 \mathrm{~h}$ light:12h dark cycle. Medium was refreshed in all algal culture flasks every 3-5 days. Exponential/log phase cultures of $R$. salina and $D$. tertiolecta were used for all of the feeding experiments and they were sampled for total lipid extraction and sterol analysis, prior to feeding them to the protists. 
The heterotrophic dinoflagellates Oxyrrhis marina Dujardin and Gyrodinium dominans Hulbert were obtained from the Shannon Point Marine Center and cultured in f/2 medium prepared from ASW of salinity 20 and fed solely on either $R$. salina or D. tertiolecta cultures. Both O. marina and G. dominans cultures used for feeding experiments were maintained in 300 $\mathrm{ml}$ bottles on a rotating plankton wheel at $1.5 \mathrm{rpm}$ in a walk-in environmental room at $19{ }^{\circ} \mathrm{C}$ in the dark.

\section{Experiments}

I. Determination of the ability of Oxyrrhis marina and Gyrodinium dominans to produce and modify dietary sterols

1) Growth and sterol profiles of Oxyrrhis marina and Gyrodinium dominans fed the alga Rhodomonas salina

To determine the kinetics (production per unit time) and efficiency (production per unit of carbon ingested) of sterol production and/or dietary sterol modification by the heterotrophic protists, O. marina and G. dominans, eighteen $300 \mathrm{ml}$ glass bottles containing $1.5 \times 10^{5}$ preydepleted $O$. marina or $G$. dominans cells in $\mathrm{f} / 2$ medium of salinity 20 , were inoculated with $1.5 \mathrm{x}$

$10^{7} \mathrm{R}$. salina cells (predator:prey $=1: 100 ; \mathrm{n}=18$ bottles) and kept in the dark at $19^{\circ} \mathrm{C}$ on a rotating plankton wheel at $1.5 \mathrm{rpm}$. Prey-depleted O. marina and G. dominans were obtained by only feeding them 3 and 4 days, respectively, with $R$. salina in a predator:prey ratio of 1:100, prior to being used for feeding experiment and sampled for cell counts and lipid analysis. 
Usually O. marina grazed down its algal prey by day 3 and G. dominans ingested almost $95 \%$ its food by day 4. However, to ensure that all prey had been consumed and metabolized $1 \mathrm{ml}$ of samples $(n=3)$ were taken to examine with an inverted microscope (Nikon, Phase contrast, ELWD, 0.3, Japan) (Chu et al. 2008) using a $1 \mathrm{ml}$ Sedgewick-Rafter counting chamber.

At the beginning of the feeding experiment, $3 \times 10^{5}$ O. marina or $G$. dominans cells (n=6), $1.5 \times 10^{7} R$. salina cells ( $\mathrm{n}=6$ ), and samples containing both $1.5 \times 10^{5}$ prey-depleted $O$. marina or prey-depleted G. dominans cells and $1.5 \times 10^{7} R$. salina cells (n=6) were harvested on acetone-rinsed GF/F filters for initial sterol profiles. Then, six bottles of cultures containing $O$. marina and $R$. salina or $G$. dominans and $R$. salina were collected on acetone rinsed GF/F filters 1, 2, and 3 days for O. marina fed $R$. salina and 1, 2, and 4 days for G. dominans fed R. salina, after inoculation ( $\mathrm{n}=6$ bottles for each sampling date) for sterol analysis. For each sampling date, three $1 \mathrm{ml}$ aliquots per bottle were taken for triplicate cell counts, which were determined by direct counting of cells stained with a 1\% Lugol's solution in a $1.0 \mathrm{ml}$ Sedgewick Rafter counting chamber using an inverted microscope (Nikon, Phase contrast, ELWD, 0.3, Japan). Then the volume of the remaining culture in each bottle was determined prior to filtration and used along with the cell counts to calculate the number of prey and predator cells in each bottle. Prey-depleted protists, algal prey, and protist-algal mixed cultures were harvested using gravity filtration, and gentle water aspiration was used only if needed. Collected sample filters were stored in glass screw cap test tubes at $-80^{\circ} \mathrm{C}$ for no more than 4 weeks prior to lipid extraction and sterol analysis. 
2) Growth and sterol profiles of Oxyrrhis marina and Gyrodinium dominans fed the alga Dunaliella tertiolecta

In the feeding experiments, in which O. marina and G. dominans were fed D. tertiolecta, the experimental conditions, predator (O. marina or G. dominans) and prey (D. tertiolecta) ratio (predator:prey $=1: 100$ ), sample replications and dates of sampling were identical to those described above for the O. marina and G. dominans fed R. salina experiments. As in the $O$. marina and G. dominans fed R. salina experiments, prey-depleted O. marina and G. dominans were obtained by only feeding them 3 and 4 days, respectively, with D.tertiolecta in a predator:prey ratio of 1:100, prior to being used for feeding experiment and sampled for cell counts and lipid analysis.

II. Total lipid extraction and sterol analysis

Lipids were extracted from the GF/F filters containing harvested cells (algae, protist, or protistalgal mixture; $\mathrm{n}=6$ for initial and each sampling) by the method of Bligh and Dyer (1959). Sterols usually account for only $\leq 10 \%$ of the protist and algal total lipids, based on our preliminary analyses. Thus, to ensure sufficient lipid quantity for sterol detection and quantitation, two replicates of the six replicate extracted lipid samples were pooled based on their cell number to generate 3 replicate lipid samples with similar cell numbers. Total lipid samples were analyzed for sterol content and composition according to a modification of the method described by Soudant et al. $(1996,1998)$. Briefly, total lipid samples were transferred to $10 \mathrm{ml}$ glass vials with $2.3 \mu \mathrm{g} 5$ - $\alpha$-cholestane added as an internal standard and evaporated to 
dryness in a warm water bath with nitrogen. Then esterified sterols contained in the total lipids were hydrolyzed to free sterols by adding $2.0 \mathrm{ml}$ sodium methoxide $\left(0.5 \mathrm{M} \mathrm{CH}_{3} \mathrm{ONa}\right.$ in $\left.\mathrm{MeOH}\right)$ to the vial and placed in a shaker for $1.5 \mathrm{hr}$ at room temperature after vortexing. After hydrolysis, free sterols were recovered and extracted with $1 \mathrm{ml}$ hexane. The hexane fraction containing the free sterols was washed with $2 \mathrm{ml}$ of water to remove any traces of MeONa prior to being analyzed by gas-liquid chromatography/flame ionization detection (GC/FID) and gas-liquid chromatography/mass spectroscopy (GC/MS). A Varian Saturn 2000 GC/MS/MS ion trap (Varian Analytical Instruments, Walnut Creek, CA) was used for sterol qualitative analysis. The GC/MS was equipped with a Varian 3800 CP gas chromatograph (GC). A J\&W DB-5 (60mX0.32mmX0.25 $\mu \mathrm{m}$ film) fused silica column (Folsom,CA) was installed in the GC and helium was used as the carrier gas at a constant flow rate of $1.6 \mathrm{ml}$ minute ${ }^{-1}$. The injector temperature was $320^{\circ} \mathrm{C}$. All analyses used the following column temperature program: initial temperature of $75^{\circ} \mathrm{C}$ holding for 1 minute then programming at $15^{\circ} \mathrm{C} \min ^{-1}$ to a final temperature of $350^{\circ} \mathrm{C}$ holding for 9.67 minutes. The ion trap was held at $220^{\circ} \mathrm{C}$, the manifold at $80^{\circ} \mathrm{C}$ and the transfer line was $320^{\circ} \mathrm{C}$. The GC/MS/MS was operated in the electron ionization (EI) mode over a mass range of $50-650 \mathrm{~m} / \mathrm{z}$ at $0.77 \mathrm{sec} \mathrm{scan}^{-1}$. Identification of sterols was based on the comparison of their retention times relative to authentic standards, mass spectra of authentic standards, and available spectra in NIST05 and Wiley 07 mass spectral libraries. Sterol standards used for identification include cholesterol ( $\Delta 5$-C27:1), dihydrocholesterol (C27:0), brassicasterol ( $\Delta 5,22-C 28: 2)$, desmosterol ( $\Delta 5,24-C 27: 2)$, campesterol ( $\Delta 5$-C28:1), ergosterol ( $\Delta 5,7,22-\mathrm{C} 28: 3)$, stigmasterol ( $\Delta 5,22-\mathrm{C} 29: 2), \beta$-sitosterol ( $\Delta 5$-C29:1) and fucosterol ( $\Delta 5,24(28)-\mathrm{C} 29: 2)$. The identification of 22-dehydrocholesterol ( $\Delta 5,22-\mathrm{C} 27: 2)$, fungisterol ( $\Delta 7-\mathrm{C} 28: 1)$ and 7dehydroporiferasterol $(\Delta 5,7,22-\mathrm{C} 29: 3)$ was established based on mass spectra described in 
literature (Fig. 1) (Gealt et al. 1981; Patterson, et al. 1992). The location of the double bond in the identified dehydrocholesterol is in C22 rather than C7 since the retention time of it is apart from the retention time of the 7-dehydrocholesterol standard and its fragmentation pattern is different from the one of 7-dehydrocholesterol standard. Several unknown sterols were present in the heterotrophic protist, Gyrodinium dominans after feeding on the alga, Rhodomonas salina or Dunaliella tertiolecta. These unknown sterols were tentatively identified based on mass spectra as: C29:0, C29:1a, C29:1b, C29:2, C30:0, C30:1, and C30:2. No authentic standards or published spectra were found that provided unambiguous identification. A Varian 3800 GC/FID (Varian Analytical Instruments, Walnut Creek, CA) equipped with a Restek RTX-65 capillary column (Crossbond 65\% diphenyl-35\% dimethylpolysiloxane; 15 m X 0.25 mm; $0.25 \mu \mathrm{m}$ film thickness (RESTEK, Bellefonte, PA, USA) was employed for sterol quantitative analysis using using 5 - $\alpha$-cholestane as an internal standard. Injection port and detector temperatures were $280^{\circ} \mathrm{C}$ and $310^{\circ} \mathrm{C}$, respectively. Helium was used as a carrier gas at a flow rate of $2 \mathrm{ml} \mathrm{min}^{-1}$ and the flow rates of air and hydrogen were 300 and $30 \mathrm{ml} \mathrm{min}^{-1}$. The column temperature was programmed from an initial temperature of 50 to $240^{\circ} \mathrm{C}$ at $20^{\circ} \mathrm{C} \mathrm{min}^{-1}$, then 240 to $300^{\circ} \mathrm{C}$ at $4{ }^{\circ} \mathrm{C}$ $\min ^{-1}$ followed by a hold at $300^{\circ} \mathrm{C}$ for $10 \mathrm{~min}$. The quantity of each identified sterol was calculated based on the relative response of cholesterol to the internal standard 5- $\alpha$-cholestane.

III. Carbon content measurements of heterotrophic protists and algae

Algal and protist carbon contents were determined previously (Chu et al. 2008) using a procedure modified from Smith et al. (2000). Briefly, algae and protists were filtered through precombusted ( $450^{\circ} \mathrm{C}$ for $2 \mathrm{hr}$ ) Whatman GF/F filters under low vacuum. The filters, inside 
precombusted glass tubes, were placed in a desiccator containing a Petri dish filled with concentrated $\mathrm{HCl}$ for $6 \mathrm{hr}$ to remove inorganic carbonates; afterward they were capped with combusted aluminum foil and dried at $60^{\circ} \mathrm{C}$. Samples were analyzed using a Carlo-Erba Model EA 1108 elemental analyzer for flash combustion. Filter blanks were precombusted GF/F filters that were analyzed the same as samples and these values were subtracted from the final carbon values and then algal and protist carbon contents were calculated using carbon-cell conversion factors (pg C/cell).

IV. Statistical analyses

The significance of the changes in contents (ng) of individual sterols and total sterols (ng) in culture bottles over time were analyzed by analysis of variance (1-way ANOVA). When results were significant $(\mathrm{p}<0.05)$, Tukeys test was employed to discriminate the means.

\section{RESULTS}

I. Sterol profiles of Rhodomonas salina, Dunaliella tertiolecta, prey-depleted Oxyrrhis marina and Gyrodinium dominans inocula used for the feeding experiments

The algal prey $R$. salina contains predominantly brassicasterol (Fig.1; $\Delta 5,22-\mathrm{C} 28: 2 ; \cong$ 99\%; Table 1) and a small amount of cholesterol (Fig.1; $\Delta 5-$ C27:1; $\cong 1-1.4 \%$, Table 1). Both of these two sterols have a $\Delta 5$ double bond. The identified brassicasterol is believed to be 
epibrassicasterol [24- $\alpha$-methylcholesta-5,22-dien-3 $\beta$-ol] (Goad et al. 1983, Bec et al. 2006). The major sterols in D. tertiolecta are ergosterol (Fig. 1, $\Delta 5,7,22-C 28: 3)$, 7-dehydroporiferasterol (Fig.1; $\Delta 5,7,22-C 29: 3)$ and fungisterol (Fig.1; $\Delta 7-C 28: 1)$. Ergosterol, 7-dehydroporiferasterol and fungisterol account for approximately 45-49\%, 29-31\% and 21-26\%, respectively for the total sterols (Table 2).

The prey-depleted $O$. marina that had been last fed $R$. salina 3 days prior to being used for feeding experiments, had a similar sterol profile to its algal prey, containing both

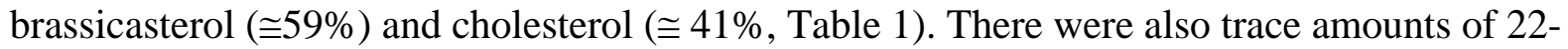
dehydrocholesterol (Fig. 1) and stigmasterol ( $\Delta 5$, 22-C29:2, Fig. 1). The sterol composition of the prey-depleted $G$. dominans that had been last fed $R$. salina 3 days previously differed from its algal prey. In addition to cholesterol (@6\%) and brassicasterol (3\%), the prey-depleted $G$.

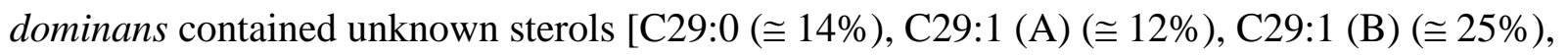

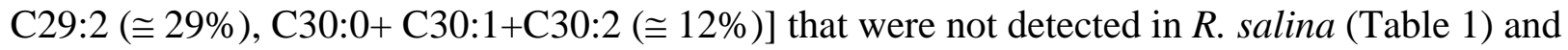
trace amounts of 22-dehydrocholesterol $(\Delta 5,22-\mathrm{C} 27: 2)$ and desmosterol $(\Delta 5,24-\mathrm{C} 27: 2)$. The sterols C29:1a and C29:1b are most likely stereoisomers at one carbon position, or differ in the location of the double bond. The sterol C29:1b is tentatively identified as 24-ethyl cholest-22en-3 $\beta$-ol based on fragmentation pattern compared to a published spectrum (Ghosh 1998).

The sterol profiles of prey-depleted O. marina and G. dominans that had last been fed with D. tertiolecta 3 and 4 days prior to being used for feeding experiments, differed significantly from their algal prey, particularly G. dominans (Table 2). Both protists contained sterols which were not detected in D. tertiolecta. Other than those found in the diet (ergosterol, 
fungisterol, and 7-dehydroporiferasterol), O. marina contained cholesterol (53\%), stigmasterol

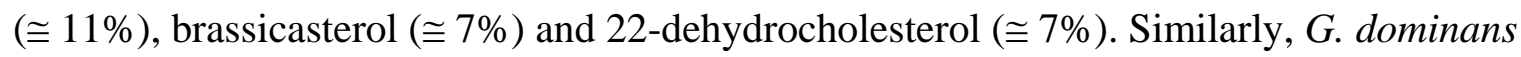

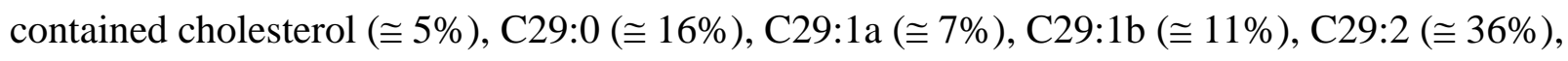

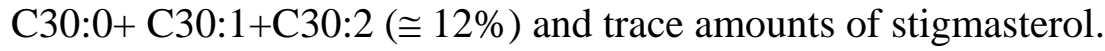

II. Growth and sterol profiles of Oxyrrhis marina and Gyrodinium dominans fed the alga Rhodomonas salina

1) Predator-prey dynamics of Oxyrrhis marina and Gyrodinium dominans fed the alga Rhodomonas salina

Rhodomonas salina was rapidly ingested and consumed by O. marina. By the day 1

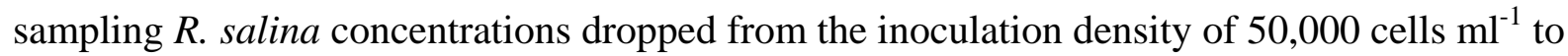
less than half $\left(23,651 \pm 3,689\right.$ cells ml $\left.^{-1}\right)$ while $O$. marina increased more than two-fold $(1,109 \pm$ 82 cells $\mathrm{ml}^{-1}$ ) and reached 4,073 \pm 209 cells ml $^{-1}$ by day 3 (Fig. 2A). Similarly, G. dominans ingested and consumed $R$. salina, though rates of ingestion and replication were much slower

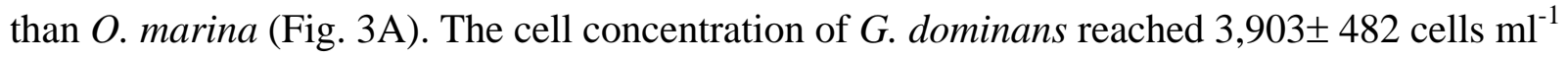
at day 4 .

2) Changes in sterol contents and profiles in Oxyrrhis marina and Gyrodinium dominans fed the alga Rhodomonas salina

A) Oxyrrhis marina fed Rhodomonas salina 
Total sterol and brassicasterol content decreased over the course of the feeding experiment (Table 3, Fig. 2B). The decline in the quantity of brassicasterol coincided with an increase in cholesterol as the protists replicated (Fig. 2A, 2B). The amount of cholesterol increased, in O. marina $-R$. salina cultures, from the initial $115.6 \pm 11.1 \mathrm{ng}$ to $452 \pm 31.5 \mathrm{ng}$ at day 3, while brassicasterol decreased from the initial 5,463.2 $\pm 361.6 \mathrm{ng}$ to $1,636.8 \pm 57.3 \mathrm{ng}$. There were also trace amounts of 22-dehydrocholesterol present. The decrease of brassicasterol accounted for the decrease of total sterol over time.

B) Gyrodinium dominans fed Rhodomonas salina

As G. dominans grazed down R. salina and proliferated, the quantity of brassicasterol declined significantly over time, from the initial 8,044.2 $\pm 105.2 \mathrm{ng}$ to $893.4 \pm 101.6 \mathrm{ng}$ at day 4 (Table 4). In contrast, as the protists proliferated, cholesterol and the unknown sterols C29:1a, C29:1b, C29:2, C29:0 and C30:2 +C30:1+C30 increased in abundance over time (Table 4, Fig. 3A, 3B). The amount of cholesterol augmented significantly at the end of the feeding experiment, from the initial $77.9 \pm 21.8 \mathrm{ng}$ to $1,916.6 \pm 702.0 \mathrm{ng}$ at day 4 , while 22 dehydrocholesterol decreased significantly from the initial $93.9 \pm 4.4 \mathrm{ng}$ to a trace amount at day 4. Total sterol content increased slightly, but not significantly, over time. There was a trace amount of desmosterol, which was not detected in the algal prey, $R$. salina, but present in the prey-depleted G. dominans (Table 1). 
III. Growth and sterol profiles of Oxyrrhis marina and Gyrodinium dominans fed the alga Dunaliella tertiolecta

1) Predator-prey dynamics of Oxyrrhis marina and Gyrodinium dominans fed the alga Dunaliella tertiolecta

As previously reported (Chu et al. 2008), O. marina quickly grazed down D. tertiolecta (Fig. 4A). The pattern of grazing and growth of G. dominans was similar to O. marina, but much slower than O. marina (Fig. 5A). The cell densities of O. marina and G. dominans were 2,767 \pm

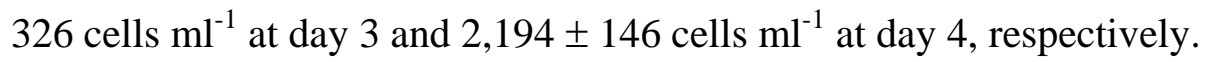

2) Changes in sterol contents and profiles in Oxyrrhis marina and Gyrodinium dominans fed the alga Dunaliella tertiolecta

A) Oxyrrhis marina fed Dunaliella tertiolecta

The sterol species, ergosterol, fungisterol, and 7-dehydroporiferasterol, derived from $D$. tertiolecta decreased over time as O. marina proliferated (Table 5, Fig. 4A, 4B). 22dehydrocholesterol and brassicasterol increased from the initial 103.6 $\pm 11.2 \mathrm{ng}$ and $87.0 \pm 16.6$ ng to $1,934.6 \pm 123.6 \mathrm{ng}$ and $689.8 \pm 28.1 \mathrm{ng}$ respectively at day 2, corresponding to 19 and 9 fold increases, then decreased to 1,220.7 $\pm 56.7 \mathrm{ng}$ and $355.2 \pm 30.6 \mathrm{ng}$ respectively, at day 3 (Table 5). Similarly, stigmasterol increased to $316.9 \pm 18.8 \mathrm{ng}$ from the initial $276.7 \pm 28.9 \mathrm{ng}$ at day 1 , then decreased afterward, to $120.9 \pm 3.8 \mathrm{ng}$ at day 3 . The content of cholesterol remained 
static over the course of the feeding experiment (Table 5, Fig. 4B). Total sterol content increased from the initial 3,383.1 $\pm 168.3 \mathrm{ng}$ to $4,059.9 \pm 114.4 \mathrm{ng}$ at day 1 and $4,059.0 \pm 208.5$ at day 2 then decreased to 2,854.4 \pm 66.9 ng (Table 5). The increases and decreases of 22dehydrocholesterol, brassicasterol and stigmasterol probably accounted for the up and down of total sterol content. Cholesterol, stigmasterol, brassicasterol, and 22-dehydrocholesterol, which were not found in D. tertiolecta, but present in prey-depleted O. marina (Table 2) and in the protist during feeding, must be produced by the protist via bioconversion of phytosterols or de novo synthesis.

\section{B) Gyrodinium dominans fed Dunaliella tertiolecta}

Total sterol content did not change significantly until day 4. By day 4 (Table 6), total sterol content had increased significantly from the initial 4,194.3 \pm 665.9 ng to 9,450.5 \pm 390.3 ng (Table 6). Cholesterol levels fluctuated over time and increased significantly from the initial $85.0 \pm 23.3 \mathrm{ng}$ to $978.6 \pm 155.7 \mathrm{ng}$ at day 1 then decreased to $113.4 \pm 36.3 \mathrm{ng}$ at day 2 , then increased back to a level similar to day 2 at day 4 (892.7 $\pm 121.2 \mathrm{ng})$. Similarly the amount of fungisterol increased significantly at day 1 , then decreased to a level similar to day 0 at day 2, but at day 4 it increased back to a level similar to day 1 . Sterols including unknown sterols that were present in prey depleted G. dominans cultures, but not found in D. tertiolecta cultures increased in parallel with G. dominans proliferation (Fig. 5A, 5B): brassicasterol (from the initial $135.0 \pm 38.4 \mathrm{ng}$ to $695.3 \pm 87.9 \mathrm{ng}$ at day 4 ), C29:0 (from the initial $157.7 \pm 68.4 \mathrm{ng}$ to $1,304.7 \pm$ $119.1 \mathrm{ng}$ ) C29:1a (from the initial $338.1 \pm 243.9 \mathrm{ng}$ to $937.3 \pm 29.9 \mathrm{ng}$ at day 4), C29:1b (from the initial $661.2 \pm 18.4$ to $1,074.1 \pm 100.9 \mathrm{ng}$ at day 4), C29:2 (from the initial $166.6 \pm 144.7$ to 
$1779.6 \pm 203.6$ ng at day 4), and C30:2+C30:1+C30:0 (from the initial 284.0 \pm 40.9 ng to 688.9 $\pm 185.3 \mathrm{ng}$ ). In contrast, ergosterol, one of the major sterols present in D. tertiolecta, decreased by almost half of its initial value at day 4 . The amount of 7-dehydroporiferasterol did not change significantly over time. Trace amounts of stigmasterol were also present.

IV) Efficiency of cholesterol production (ng cholesterol per unit of carbon ingestion) by heterotrophic protists at the phytoplankton-heterotrophic protist interface

Sterols produced by both $O$. marina and $G$. dominans include cholesterol and brassicasterol. Cholesterol was produced when the heterotrophs were fed either $R$. salina or $D$. tertiolecta, but brassicasterol was only produced when $D$. tertiolecta was the algal prey. Additionally, O. marina produced 22-dehydrocholesterol when fed D. tertiolecta and G. dominans produced seven unknown 29 and 30 carbon sterols when fed either $R$. salina or $D$. tertiolecta. All other sterols detected in the feeding experiments either decreased over time or fluctuated in abundance. Since cholesterol was the only sterol produced by both heterotroph species regardless of algal prey species and it is by far the most abundant sterol in marine organisms at higher trophic levels the production efficiencies of cholesterol by O. marina and G. dominans were determined.

Cholesterol production by heterotrophic protists was calculated using carbon content values derived from direct measurement (Table 7). Production efficiency was defined as the ng sterol present in each culture bottle at the end of a feeding experiment minus the ng of sterol contained in the inoculum and in unconsumed algae normalized to the mg of algal carbon 
consumed by the heterotrophic protist [production efficiency $=$ (final ng sterol - (inoculum ng sterol + ng unconsumed algal sterol) $) \div$ mg algal C consumed]. Both protist species appear to be able to produce cholesterol either via bioconversion of dietary sterols or de novo synthesis.

When G. dominans and O. marina were fed with $R$. salina, which contains mainly brassicasterol, both protists assimilated and/or produced significant amounts of cholesterol, probably, at the expense of brassicasterol (Tables 3 and 4). Calculation according to carbon contents derived from direct algal measurement are equivalent to a production of $987.7 \pm 377.7 \mathrm{ng}$ and $172.5 \pm$ 16.2 ng cholesterol per mg $R$. salina carbon consumed by G. dominans and O. marina, respectively. Compared to the cholesterol concentration (cholesterol per mg algal C) in $R$. salina, the levels of cholesterol were "upgraded" to a magnitude of nearly 5 to 30 fold at the phytoplankton-heterotrophic protist interface. Feeding the alga, D. tertiolecta, which contains no cholesterol, to G. dominans and O. marina, a net production of cholesterol by G. dominans and O. marina is $871.8 \pm 130.8 \mathrm{ng}$ and $123.2 \pm 30.6 \mathrm{ng}$ per $\mathrm{mg}$ D. tertiolecta carbon consumed, respectively (Table 7).

\section{DISCUSSION}

As indicated earlier, sterols, or closely related compounds, are important nutrients for all eukaryotic organisms. Sterol requirements for the genus Daphnia, the dominant metazoan grazer in freshwater habitats, and copepods, the dominant metazoan grazer in marine environments have been addressed by several studies (Klein Breteler et al. 1999, 2004, 2005; Crockett and Hassett 2005; Martin-Creuzburg et al. 2005a, 2005b, 2006, 2008; Bec et al. 2006). Not only is dietary sterol content one of the crucial factors in determining food quality for Daphnia (Von 
Elert et al. 2003; Martin-Creuzburg and Von Elert 2004; Martin-Creuzburg et al. 2005b), but the sterol species present in the diets also appears to be critical for the cladoceran's survival, growth and reproduction, although sterol-like compounds such as tetrahymanol and hopanoids could serve as sterol surrogates and partially release Daphnia fed on a sterol-deficient diet from sterol limitation (Martin-Creuzburg et al. 2005a). As with their freshwater counterpart, Daphnia, dietary essential fatty acids and sterols are essential and could limit the reproductive output and somatic growth of copepods (Klein Breteler et al. 1999, 2004, 2005; Crockett and Hassett 2005). Thus, algal sterol content and quality are potential limiting factors regulating/controlling the dynamic of metazoan grazer populations such as Daphnia and copepods, thereby determining the structure of aquatic food webs. However, sterol- limited growth and production could be ameliorated by insertion of an additional intermediary trophic level. As trophic links, the heterotrophic ciliates, Colpidium campylum and Cyclidium sp., and the heterotrophic nanoflagellate, Paraphysomons sp. were able to upgrade the food quality of their prey by producing essential fatty acids, sterols or sterol-like compounds and subsequently enhance the growth and reproduction of their predator, Daphnia (Martin-Creuzburg et al. 2005a, 2006, 2008; Bec et al. 2006). The presence of sterols in the nanoflagellate Paraphysomons sp. was credited for the improved growth and increased fecundity in D. magna fed the nanoflagellate previously maintained on cyanobacteria which are deficient in sterols (Bec et al. 2006). Similarly, feeding the 2 copepods, Temora longicornis and Pseudocalanus elongatus the heterotrophic protist, $O$. marina previously fed with Dunaliella sp., which contains low level of sterol and is deficient in LCn-3 EFA, significantly enhanced survivorship and development of copepod young nauplius larvae relative to a copepod diet of $D$. tertiolecta alone (Klein Breteler et al. 1999). Increased sterol content and production of new sterol species and LCn-3 EFAs by O. marina fed 
Dunaliella sp. is believed to be the key factor contributing to the maturity improvement in the two tested copepod species.

However, presently the quantitative significance of sterol upgrading and/or repacking by heterotrophic protists in both freshwater and marine ecosystems is unclear. The effectiveness and quantitative significance of sterol production and phytosterol bioconversion at the phytoplankton-heterotrophic protist interface has not been determined. The present study is the first investigating/examining the kinetics and efficiency of sterol production and bioconversion of phytosterols by heterotrophic protists and their quantitative significance. Additionally, although $O$. marina seems able to synthesize sterols and/or modify those present in its diet (Klein Breteler et al. 1999; Adolf et al. 2007), it is uncertain if other species have similar capabilities. There is a need to investigate if sterol synthesis and/or modification are a widespread phenomenon among heterotrophic protists and its ecological effects. No evidence was noted for sterol synthesis in a ciliate (Strombidium sulcatum) studied by Klein Breteler et al. (2004).

Consistent with previous findings (Goad et al. 1983; Klein Breteler et al. 1999; Leblond

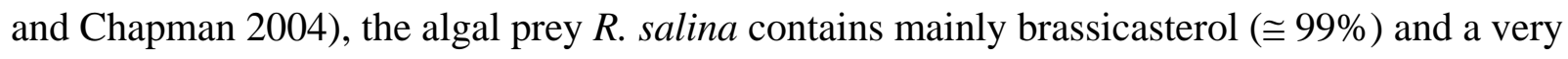

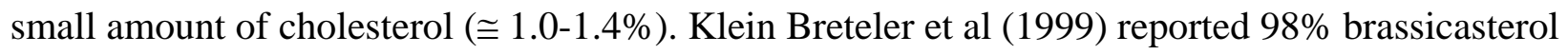
and 2\% cholesterol in R. salina. The identified brassicasterol in the present study is believed to be epibrassicasterol (Goad et al. 1983; Bec et al. 2006). Three major sterols, 7dehydroporiferasterol (38-50\%), ergosterol (28-36\%) and fungisterol (14-22\%) were noted in $D$. tertiolecta. Previous studies also noted high levels of 7-dehydroporiferasterol (46\%) and ergosterol (22\%) in D. tertiolecta (Patterson et al. 1992; Zelazny et al. 1995). On the other hand, 
in another two studies, only fungisterol (trace amount and $0.7 \mu g \mathrm{mg} \mathrm{C}^{-1}$ ) and trace amounts of $\Delta 7-\mathrm{C} 29: 1, \Delta 7,24(28)-\mathrm{C} 28: 2$ and $\Delta 7,24(28)-\mathrm{C} 29: 2$ were found in D. tertiolecta (Klein Breteler et al. 1999; Klein Breteler et al. 2004). However, these last two studies did not utilize authentic sterol standards for identification and did not provide detailed information about how sterols were identified using GC/MS, thus making it difficult to compare our results with theirs.

Our results demonstrate clearly that the two examined protists, Oxyrrhis marina and Gyrodinium dominans, are capable of producing new sterols species via either bioconversion of dietary sterols or de novo synthesis. The sterol profiles of both heterotrophic protist species do not completely reflect their algal diets. It is interesting to note the variety of sterols, both in quantity and quality, found in the protists but not in the algal prey after feeding with the two algal species. Considering that $R$. salina contains almost exclusively brassicasterol (99\%) but low levels of cholesterol (1-1.4\%), the amounts and percentage of cholesterol found in the two protists after feeding with this alga (Tables 1, 3 and 4) are noteworthy. The dramatic decrease of brassicasterol concomitant with the increase of cholesterol in the two protist species during the feeding experiments suggest that protists selectively and effectively assimilated cholesterol and probably catabolized brassicasterol for energy. Alternatively they might have converted brassicasterol to 22-dehydrocholesterol by dealkylation (removal of the methyl group from C-24) and then to cholesterol by hydrogenation (hydrogenation of the double bond at C22). Similarly, when the two protist species were fed with D. tertiolecta, which contains primarily ergosterol, 7dehydroporiferasterol, and fungisterol, other sterols not found in the prey appeared in the predators (Tables 2, 5 and 6). These sterols include cholesterol, stigmasterol, brassicasterol, 22dehydrocholesterol, and desmosterol. Additionally, several C29 and C30 unknown sterols were 
found in G. dominans fed with either R. salina or D. tertiolecta. In a previous study, cholesterol, dehydrocholesterol, brassicasterol, stigmasterol and campesterol were also found in O. marina fed a Dunaliella sp. containing primarily fungisterol (Klein Breteler et al. 1999). However, the levels of the newly produced sterols either fluctuated (e.g., brassicasterol and stigmasterol in $O$. marina fed $D$. tertiolecta, Table 5) over time, or decreased at the end of the feeding experiments (e.g., 22-dehydrocholesterol in G. dominans fed R. salina and O. marina fed D. tertiolecta, Tables 4 and 5) except cholesterol and unknown sterols (in G. dominans fed either R. salina or D. tertiolecta, Table 4 and 6), which increased over time. Similarly, the levels of sterols derived from algal prey either fluctuated or decreased at the end of the experiment. There is no consistent pattern. These results suggest that coupling of assimilation and bioconversion of dietary sterols took place in protists using algae as an energy source.

Mechanisms for dietary sterol modification/bioconversion could include alkylation, dealkylation, hydrogenation and dehydrogenation (Goodwin 1980). It is possible that both $O$. marina and G. dominans: (1) convert dietary brassicasterol to 22-dehydrocholesterol by dealkylation of the methyl group at C24 and then to cholesterol by hydrogenation the double bond at C22; (2) convert the dietary ergosterol to brassicasterol by hydrogenation of the double bond at C7 and then to 22-dehydrocholesterol by dealkylation or to stigmasterol by alkylation at C24; (3) convert dietary brassicasterol to cholesterol by dealkylation and hydrogenation then to 22-dehydrocholesterol by desaturation; (4) alkylation of 22-dehydrocholesterol to brassicasterol; (5) convert the dietary 7-dehydroporiferasterol to stigmasterol via hydrogenation of the double bond at C7; and (6) though unlikely, synthesize cholesterol de novo, then converted it to 22dehydrocholesterol via dehydrogenation (desaturation). Therefore, 22-dehydrocholesterol could 
be an important metabolic intermediate if the bioconversion pathways described in 1-4 and 6 above do take place. While different biosynthetic routes of sterols in various organisms, including algae, have been recently reviewed (Bouvier et al. 2005), the mechanisms of bioconversion of the synthesized sterols to the other sterols and associated enzymes is unclear. Thus, at this point the pathways of phytosterol bioconversions and the physiological importance/significance of sterol bioconversion in heterotrophic protists are not known. The increased cholesterol levels in O. marina and G. dominans fed R. salina and the cholesteroldeficient $D$. tertiolecta suggest that these two protists species produce cholesterol via bioconversion of phytosterols. Further planned studies using stable isotope substrates will be required to determine whether or not these two protists synthesize cholesterol de novo. Results of our preliminary trials revealed that $O$. marina cannot synthesize cholesterol de novo using ${ }^{13} \mathrm{C}$ labeled acetate provided in the medium. Our previous investigation suggest that G. dominans was unable to utilize acetate in the medium for growth or fatty acid synthesis (Lund et al. 2008).

It appears that there are species-specific differences in sterol metabolism. O. marina contains cholesterol, 22-dehydrocholesterol and brassicasterol when fed $R$. salina or $D$. tertiolecta (Tables 1, 2, 3, and 5), yet G. dominans contains cholesterol, brassicasterol, 22dehydrocholesterol, demosterol and unknown sterols (C29:1a, C29:1b, C29:2, C29:0 and C30:2, C30:1, C30:0) when fed these same algal species (Tables 1, 2, 4 and 6). Very likely, each species utilizes different modes in sterol metabolism to modify dietary sterols and/or synthesize sterols de novo. G. dominans produced significant amounts of unknown sterols when it was fed $R$. salina or D. tertiolecta. Possibly, the unknown sterols C29:1a, C29:1b, C29:2, C29:0 and C30:2, C30:1 and C30:0 found in G. dominans are alkylation products of dietary sterols. For example, adding an ethyl group to cholesterol and a methyl group to brassicaterol would produce C29:1 
and C29:2, respectively. Unknown C29 sterols with one or two double bonds were also noted in the parasitic syndinian dinoflagellate Amoebophyra sp. (Leblond et al. 2006). Dinosterol ( $\Delta 22-$ C30:1), a dominant sterol reported previously in both auto- and hetero- trophic dinoflagellates (Leblond and Chapman 2002), was not found in the Amoebophyra sp. (Leblond et al. 2006). We did not detect dinosterol in either O. marina or G. dominans.

Free sterols such as cholesterol are primarily used as membrane components and play a key role in regulating membrane permeability/fluidity (Finkelstein and Cass 1967; Bruckdorfer et al. 1969; Demel et al. 1972), osmotic sensing (Zelazny et al. 1995), and thermal tolerance (Crockett 1998). Cholesterol is not only an important membrane constituent in animals, but is also an important fundamental intermediate, a critical precursor for many physiologically functional biochemicals such as steroid hormones, bile salts, and vitamin D in higher animals and a precursor of the molting hormones, ecdysteroids in crustaceans (Fingerman 1987). Cholesterol is the dominant sterol in crustaceans and accounts for 90-95\% of total sterols (Kanazawa 2001). Copepods may require optimal levels of cholesterol for membrane function, and cholesterol-enriched diet stimulated both egg production and hatching rates without altering the plasma membrane cholesterol content in the copepod Acartia hudsonica (Crockett and Hassett 2005). Thus, it is possible that under some conditions dietary cholesterol is a limiting factor for copepod production in nature. While some animals including mammals can synthesize cholesterol from acetate and mevalonate, crustaceans including calanoid copepods are incapable of synthesizing sterols de novo, thus dietary sources are essential. In both freshwater and marine environments, phytoplankton is the major source of sterols. Although copepods have been shown to selectively absorb specific dietary sterols (Prahl et al. 1984), the relative importance of 
particular sterols to the growth and fecundity of calanoid copepods is currently unknown. Cholesterol is by far the most prevalent sterol in metazoans, thus this may be a significant factor in the nutritional value of heterotrophic protists relative to algae for marine zooplankton.

Since in the present study we did not feed the two studied protists, $O$. marina and $G$. dominans to copepods to investigate the benefit of "cholesterol upgrading" by them, the ecological significance of "cholesterol upgrading" and "phytosterol bioconversion" by these two protists remains to be verified. However, evidence of trophic upgrading of food quality by these two heterotrophic protists fed similar algal prey has been reported in our previous study (Veloza et al. 2006) and by other investigators (Tang \& Taal 2005, Klein Breteler et al. 1999) by feeding them to copepods, though these studies focused on the impact of LCn-3 EFAs, but not sterols. Sterol production and bioconversion of dietary sterols by intermediate heterotrophic protists at the phytoplankton-zooplankton interface could be a critical issue and its ecological implication is worthy of further investigation.

In conclusion, results from the present study suggest that both $O$. marina and $G$. dominans are able to produce new sterol species not found in their diets either via bioconversion of phytosterols by alkylation (insertion of a methyl or an ethyl group), dealkylation (removal of a methyl or an ethyl group), dehydrogenation (insertion of a double bond) and hydrogenation (removal of a double bond) of dietary sterols, or de novo synthesis. The findings of effective assimilation of dietary cholesterol and bioconversion of phytosterols to cholesterol by the two tested protists may be ecologically important and has ecological implications when primary production is dominated by nano- and pico-plankton or algal species deficient in cholesterol. 
Further study is needed to determine if cholesterol production by heterotrophic protists is a crucial factor in determining food quality for zooplankton in both marine and freshwater systems. Considering the physiological and biochemical roles of cholesterol and its dominance in living organisms, “cholesterol upgrading” by heterotrophic protists is likely important in nature.

\section{ACKNOWLEDGEMENTS}

This study was supported by OCE, NSF (award \#:0525899). The authors are grateful for Jenny Dryer's help on the analysis of protist and algal carbon content. Contribution no. XXXX by the Virginia Institute of Marine Science, College of William and Mary. 


\section{REFERENCES}

Ackman RG (1989) Nutritional composition of fats in seafoods. Prog. Food Nutr. Sci. 13: 161241

Adolf JE, Krupatkina D, Bachvaroff T, Place AR (2007) Karlotoxin mediates grazing by Oxyrrhis marina on strains of Karlodinium venificum. Harmful Algae 6: 400-412

Ballantine JA, Roberts JC, Morris RJ (1980) Marine sterols: The sterols of some pelagic marine crustaceans. J Exp Mar Biol Ecol 47 : 25-33

Bec A, Desvilettes C, Vera A, Lemarchand C, Fontvielle D, Bourdier G (2003) Nutritional quality of a freshwater heterotrophic dinoflagellate: trophic upgrading of its microalgal diet for Daphnia hyalina. Aquat Microb Ecol 32: 203-207

Bec A, Martin-Creuzburg D, Von Elert E (2006) Trophic upgrading of autotrophic picoplankton by the heterotrophic nanoflagellate Paraphysomonas sp.. Limnol Oceanogr 51:1699-1707

Bligh EG, Dyer WJ (1959) A rapid method of total lipid extraction and purification. Can J Biochem Physiol 37: 911-17 
Boechat IG, Adrian R (2005) Biochemical composition of algivorous freshwater ciliates: You are not what you eat. FEMS Microbiol Ecol 53: 393-400

Bollens GCR, Penry DL (2003) Feeding dynamics of Acartia spp. copepods in a large, temperate estuary (San Francisco Bay, CA). Mar Ecol Progr Ser 257: 139-158

Bouvier F, Rahier A, Camara B (2005) Biogenesis, molecular regulation and function of plant isoprenoids. Prog Lipid Res 44: 357-429

Broglio E, Jonasdottir SH, Calbet A, Jakobsen HH, Saiz E (2003) Effect of heterotrophic versus autotrophic food on feeding and reproduction of the calanoid copepod Acartia tonsa: relationship with prey fatty acid composition. Aquat Microb Ecol 31: 267-278

Bruckdorfer KR, Demel RA, De Gier J, Van Deenen LLM (1969) The effect of partial replacement of membrane cholesterol by other sterols on the osmotic fragility and glycerol permeability of erythrocytes. Biochim Biophys Acta 183: 334-345

Chu F-LE, Lund ED, Podbesek JA (2008) Quantitative significance of n-3 essential fatty acid contribution by heterotrophic protists and its ecological implication in marine pelagic food webs. Mar Ecol Prog Ser 354: 85-95 
Crockett EL (1998) Cholesterol function in plasma membranes from ectotherms: membranespecific roles in adaptation to temperature. Am Zool 38: 291-304

Crockett EL, Hassett A (2005) Cholesterol-enriched diet enhances egg production and egg viability without altering cholesterol content of biological membranes in the copepod Acartia hudsonica. Physiol Biochem Zool 78: 424-433

Demel RA, Bruckendorf KR, Van Deenen LLM (1972) The effect of sterol structure on permeability of liposomes to glucose, glycerol and $\mathrm{Rb}^{+}$. Biochim Biophys Acta 255: 321-330

Ederington MC, McManus GB, Harvey HR (1995) Trophic transfer of fatty acids, sterols, and a triterpenoid alcohol between bacteria, a ciliate, and the copepod Acartia tonsa. Limnol Oceanogr 40: $860-867$

Fingerman M (1987) The endocrine mechanisms of crustaceans. J Crustacean Biol 7: 1-24

Finkelstein A, Cass A, (1967) Effect of cholesterol on the water permeability of thin lipid membranes. Nature 216: 717

Gealt MA, Adler JH, Nes WR (1981) The sterols and fatty acids from purified flagella of Chlamydomonas reinhardi. Lipids 16: 133-136 
Ghosh P, Patterson GW, Wikfors GH (1998) Sterols of some marine Prymnesiophyceae. J Phycol 34: 511-514

Gifford SM, Rollwagen-Bollens G, Bollens SM (2007) Mesozooplankton omnivory in the upper San Francisco Estuary. Mar Ecol Prog Ser 348: 33-46

Goad LJ, Holz GG, Beach DH (1983) Identification of (24s)-24-methylcholesta-5,22-diene-3Bol as the major sterol of a marine cryptophyte and a marine prymnesiophyte. Phytochemistry 22: $475-476$

Goodwin TW (1980) Biosynthesis of sterols. In: Stumpf PK (ed.) The biochemistry of plants, vol. 4. Academic Press, New York NY pp. 485-507

Gurr MI, Harwood JL, Frayn KN (2002) Lipid Biochemistry, $5^{\text {th }}$ ed. Blackwell Sciences Inc. Malden MA

Harvey HR, Ederington MC, McManus GB (1997) Lipid composition of the marine ciliates Pleuronema sp. and Fabrea salina: Shifts in response to changes in diet. J Eukaryot Microbiol 44: $189-193$

Hassett RP (2004) Supplementation of a diatom diet with cholesterol can enhance copepod eggproduction rates. Limnol Oceanogr 49: 488-494 
Kanazawa A (2001) Sterols in marine invertebrates. Fisheries Sci 67: 997-1007

Klein Breteler WCM, Schogt N, Baas M, Schouten S, Kraay GW (1999) Trophic upgrading of food quality by protozoans enhancing copepod growth: Role of essential lipids. Mar Biol $135: 191-198$

Klein Breteler WCM, Koski M, Rampen S (2004) Role of essential lipids in copepod nutrition: no evidence of trophic upgrading of food quality by a marine ciliate. Mar Ecol Prog Ser 274: $199-208$

Klein Breteler WCM, Schogt N, Rampen S (2005) Effect of diatom nutrient limitation on copepod development: role of essential lipids. Mar Ecol Prog Ser 291: 125-133

Leblond JD, Chapman PJ (2002) A survey of the sterol composition of the marine dinoflagellates Karenia brevis, Karenia mikimotoi, and Karlodinium micrum: Distribution of sterols within other members of the class Dinophyceae. J Phycol 38: 670-682

Leblond JD, Chapman PJ (2004) Sterols of the heterotrophic dinoflagellate, Pfiesteria piscicida (Dinophyceae): is there a lipid biomarker? J Phycol 40: 104-111

Leblond JD, Sengco MR, Sickman JO, Dahmen JL, Anderson DM (2006) Sterols of the syndinian dinoflagellate Amoebophrya sp., a parasite of the dinoflagellate Alexandrium tamarense (Dinophyceae). J Eukaryot Microbiol 53: 211-216 
Lund ED, Chu F-LE, Harvey E, Adolf R (2008) Mechanism(s) of long chain n-3 essential fatty acid production in two species of heterotrophic protists: Oxyrrhis marina and Gyrodinium dominans. Mar Biol 155: 23-36

Martin-Creuzburg D, Von Elert E (2004) Impact of 10 Dietary Sterols on Growth and Reproduction of Daphnia galeata. J Chem Ecol 30: 483-500

Martin-Creuzburg D, Bec A, Von Elert E (2005a) Trophic upgrading of picocyanobacterial carbon by ciliates for nutrition of Daphnia magna Aquat Microb Ecol 41: 271-280

Martin-Creuzburg D, Wacker A, Von Elert E (2005b) Life history consequences of sterol availability in the aquatic keystone species Daphnia. Oecologia 144: 362-372

Martin-Creuzburg D, Bec A, Von Elert E (2006) Supplementation with sterols improves food quality of a ciliate for Daphnia magna. Protist 157: 477-486

Martin-Creuzburg D, Von Elert E, Hoffmann K (2008) Nutritional constraints at the cyanobacteria-Daphnia magna interface: The role of sterols. Limnol Oceanogr 53: 456-468

Merrell JR, Stoecker DK (1998) Differential grazing on protozoan microplankton by developmental stages of the calanoid copepod Eurytemora affinis. J Plankton Res 20: 289-304 
Ohman MD, Runge JA (1994) Sustained fecundity when phytoplankton resources are in short supply: Omnivory by Calanus finmarchicus in the Gulf of St. Lawrence. Limnol Oceanogr 39: 21-36

Patterson GW, Gladu PK, Wikfors GH, Lusby WR (1992) Unusual tetraene sterols in some phytoplankton. Lipids 27: 154-156

Prahl FG, Eglinton G, Corner EDS, O'Hara SCM, Forsberg TEV (1984) Changes in plant lipids during passage through the gut of Calanus. J Mar Biol Ass UK 64: 317-334

Smith WJ, Marra J, Hiscock M, Barber R (2000) The seasonal cycle of phytoplankton biomass and primary productivity in the Ross Sea, Antarctica Deep-Sea Res (II Top Stud Oceanogr) 47: $3119-3140$

Soudant P, Marty Y, Moal J, Robert R, Quere C, Le Coz, JR, Samain JF (1996) Effect of food fatty acid and sterol quality on Pecten maximus gonad composition and reproduction process. Aquaculture $143: 361-378$

Soudant P, Le Coz JR, Marty Y, Moal J, Robert R, Samain JF (1998) Incorporation of microalgae sterols by scallop Pecten maximus (L.) larvae. Comp Biochem Physiol 119A: 451457 
St. John MA, Lund T (1996) Lipid biomarkers: Linking the utilization of frontal plankton biomass to enhanced condition of juvenile North Sea cod. Mar Ecol Prog Ser 131: 75-85

St. John MA, Clemmesen C, Lund T, Koester T (2001) Diatom production in the marine environment: implications for larval fish growth and condition. ICES J Mar Sci 58: 1106-1113

Tang K, Taal M (2005) Trophic modification of food quality by heterotrophic protists: speciesspecific effects on copepod egg production and egg hatching. J Exp Mar Biol Ecol 318: 85-98

Veloza AJ, Chu F-.E, Tang KW (2006) Trophic modification of essential fatty acids by heterotrophic protists and its effects on the fatty acid composition of the copepod Acartia tonsa. Mar Biol 148: 779-788

Volkman JK (2003) Sterols in microorganisms. Appl Microbiol Biotechnol 60: 495-506

Von Elert E, Martin-Creuzburg D, Le Coz,JR (2003) Absence of sterols constrains carbon transfer between cyanobacteria and a freshwater herbivore (Daphnia galeata). Proc R. Soc London B 270: 1209-1214

Zelazny AM, Shaish A, Pick U (1995) Plasma membrane sterols are essential for sensing osmotic changes in the halotolerant alga Dunaliella. Plant Physiol 109: 1395-1403 


\section{FIGURE LEGENDS}

Figure 1 : Structures of major sterols founded in protists and the algae; Each sterol is represented by a body group and a side chain structure; a, b, c = body (R) structures ; 1 to 5 = side chain (SC) structures; Fungisterol $=1 \mathrm{a} ;$ Ergosterol $=2 \mathrm{~b} ;$ 7-dehydroporiferasterol $=3 \mathrm{~b} ;$ Brassicasterol $=2 \mathrm{c}$ ; Stigmasterol $=3 \mathrm{c} ;$ 22-dehydrocholesterol $=4 \mathrm{c} ;$ Cholesterol $=5 \mathrm{c} ; 29: 1=3 \mathrm{~d}$ (possibly).

Figure 2: (A) Predator-prey dynamic of Oxyrrhis marina fed Rhodomonas salina (n=6 bottles of cultures at each sampling date); (B) Changes of sterol profile and content in Oxyrrhis marina fed Rhodomonas salina. All values are mean \pm SD of 3 replicates, each of which is derived from the pooled lipids of 2 culture bottles.

Figure 3: (A) Predator-prey dynamic of Gyrodinium dominans fed Rhodomonas salina (n=6 bottles of cultures at each sampling date); (B) Changes of sterol profile and content in Gyrodinium dominans fed Rhodomonas salina. All values are mean \pm SD of 3 replicates, each of which is derived from the pooled lipids of 2 culture bottles. Unknown sterols: sum of 29:0, 29:1a, 29:1b, 29:2, 30:0, 30:1 and 30:2.

Figure 4: (A) Predator-prey dynamic of Oxyrrhis marina fed Dunaliella tertiolecta ( $\mathrm{n}=6$ bottles of cultures at each sampling date); (B) Changes of sterol profile and content in Oxyrrhis marina fed Dunaliella tertiolecta. All values are mean \pm SD of 3 replicates, each of which is derived from the pooled lipids of 2 culture bottles. 
Figure 5: (A) Predator-prey dynamic of Gyrodinium dominans fed Dunaliella tertiolecta $(\mathrm{n}=6$ bottles of cultures at each sampling date); (B) Changes of sterol profile and content in Gyrodinium dominans fed Dunaliella tertiolecta. All values are mean \pm SD of 3 replicates, each of which is derived from the pooled lipids of 2 culture bottles. Unknown sterols: sum of 29:0, 29:1a, 29:1b, 29:2, 30:0, 30:1 and 30:2. 
Table 1. Sterol composition and content of Rhodomonas salina used as prey for two heterotroph feeding experiments and preydepleted cultures of Oxyrrhis marina and Gyrodinium dominans previously maintained on $R$. salina for 3 and 4 days respectively. All values are mean \pm SD of 3 replicates, each of which was derived from the pooled lipids of two culture bottles.

\begin{tabular}{|c|c|c|c|c|c|c|c|c|}
\hline \multirow[b]{2}{*}{ Sterol } & \multicolumn{2}{|c|}{ O. marina } & \multicolumn{2}{|c|}{ R. salina } & \multicolumn{2}{|c|}{ G. dominans } & \multicolumn{2}{|c|}{ R. salina } \\
\hline & ng & $\%$ & ng & $\%$ & ng & $\%$ & ng & $\%$ \\
\hline 22-dehydrocholesterol & trace & -- & & & trace & -- & & \\
\hline $\begin{array}{l}\text { Cholesterol } \\
\text { Desmosterol }\end{array}$ & $103.3 \pm 6.4$ & $41.2 \pm 1.9$ & $72.7 \pm 1.2$ & 1.4 & $\begin{array}{c}36.6 \pm 12.2 \\
\text { trace }\end{array}$ & $\begin{array}{c}5.6 \pm 2.1 \\
--\end{array}$ & $64.9 \pm 4.7$ & $0.8 \pm 0.1$ \\
\hline Brassicasterol & $147.2 \pm 4.5$ & $58.8 \pm 1.9$ & $5120.2 \pm 221.1$ & 98.6 & $22.3 \pm 5.8$ & $3.4 \pm 1.0$ & $7920.1 \pm 258.3$ & $99.2 \pm 0.1$ \\
\hline $\begin{array}{l}\text { Stigmasterol } \\
{ }^{*} \mathrm{C} 29: 0\end{array}$ & trace & -- & & & $90.0 \pm 6.2$ & $13.6 \pm 0.6$ & & \\
\hline *C29:1a & & & & & $79.6 \pm 11.9$ & $12.1 \pm 1.6$ & & \\
\hline${ }^{*} \mathrm{C} 29: 1 \mathrm{~b}$ & & & & & $161.7 \pm 10.0$ & $24.5 \pm 0.6$ & & \\
\hline$*^{*} \mathrm{C} 29: 2$ & & & & & $187.8 \pm 14.2$ & $28.5 \pm 1.2$ & & \\
\hline $\begin{array}{c}{ }^{*} \mathrm{C} 30: 0+* \mathrm{C} 30: 1+ \\
{ }^{*} \mathrm{C} 30: 2\end{array}$ & & & & & $81.1 \pm 4.7$ & $12.3 \pm 0.6$ & & \\
\hline Total & $250.5 \pm 6.6$ & & $5192.9 \pm 225.2$ & & $659 . \pm 124.1$ & & $7985.0 \pm 257.3$ & \\
\hline \#cells & $3 \times 10^{5}$ & & $3 \times 10^{7}$ & & $3 \times 10^{5}$ & & $3 \times 10^{7}$ & \\
\hline
\end{tabular}

22-dehydrocholesterol $=\Delta 5,22-\mathrm{C} 27: 2 ;$ cholesterol $=\Delta 5-\mathrm{C} 27: 1$; brassicasterol $=\Delta 5,22-\mathrm{C} 28: 2 ;$ desmosterol $=\Delta 5,24-\mathrm{C} 27: 2$; stigmasterol $=\Delta 5,22-\mathrm{C} 29: 2$; trace $<20 \mathrm{ng}$. $*$ Sterols are identified with number of carbon atoms and number of double bonds based on molecular mass determined by GC/MS analyses. The number of prey-depleted cells used for sterol analyses was twice the number used in the feeding experiments; values presented in the table have been normalized to the number of cells used for inoculations in feeding experiments (Tables 3 and 4 ). 
Table 2. Sterol composition and content of Dunaliella tertiolecta used as prey for two heterotroph feeding experiments and preydepleted cultures of Oxyrrhis marina and Gyrodinium dominans previously maintained on D. tertiolecta for 3 and 4 days respectively. All values are mean $\pm S D$ of 3 replicates, each of which was derived from the pooled lipids of two culture bottles.

\begin{tabular}{|c|c|c|c|c|c|c|c|c|}
\hline \multirow[b]{2}{*}{ Sterol } & \multicolumn{2}{|c|}{ O. marina } & \multicolumn{2}{|c|}{ D. tertiolecta } & \multicolumn{2}{|c|}{ G. dominans } & \multicolumn{2}{|c|}{ D. tertiolecta } \\
\hline & ng & $\%$ & ng & $\%$ & ng & $\%$ & ng & $\%$ \\
\hline 22-dehydrocholesterol & $40.7 \pm 1.4$ & $7.0 \pm 0.2$ & & & trace & -- & & \\
\hline Cholesterol & $307.4 \pm 7.8$ & $53.2 \pm 1.3$ & & & $56.7 \pm 7.6$ & $5.3 \pm 0.7$ & & \\
\hline Desmosterol & & & & & trace & -- & & \\
\hline Brassicasterol & $41.2 \pm 4.3$ & $7.1 \pm 0.8$ & & & trace & -- & & \\
\hline Ergosterol & $31.5 \pm 6.4$ & $5.4 \pm 1.1$ & $824.3 \pm 166.5$ & $45.2 \pm 8.9$ & $9.7 \pm 16.9$ & $0.9 \pm 1.6$ & $1447.7 \pm 101.8$ & $48.6 \pm 1.7$ \\
\hline Fungisterol & $31.5 \pm 6.3$ & $5.5 \pm 1.1$ & $466.0 \pm 167.9$ & $25.5 \pm 8.8$ & $52.5 \pm 20.6$ & $4.9 \pm 1.8$ & $622.4 \pm 98.1$ & $20.8 \pm 1.6$ \\
\hline Stigmasterol & $64.4 \pm 4.0$ & $11.1 \pm 0.7$ & & & trace & & & \\
\hline 7-dehydroporiferasterol & $61.0 \pm 6.2$ & $10.6 \pm 1.1$ & $530.6 \pm 163.8$ & $29.3 \pm 9.5$ & $80.5 \pm 8.6$ & $7.5 \pm 0.7$ & $911.5 \pm 88.8$ & $30.6 \pm 2.4$ \\
\hline *C29:0 & & & & & $168.3 \pm 1.9$ & $15.7 \pm 0.8$ & & \\
\hline${ }^{*} \mathrm{C} 29: 1 \mathrm{a}$ & & & & & $72.5 \pm 8.9$ & $6.7 \pm 0.7$ & & \\
\hline${ }^{*} \mathrm{C} 29: 1 \mathrm{~b}$ & & & & & $122.4 \pm 18.7$ & $11.4 \pm 1.6$ & & \\
\hline${ }^{*} \mathrm{C} 29: 2$ & & & & & $384.9 \pm 29.1$ & $35.8 \pm 2.4$ & & \\
\hline $\begin{array}{c}{ }^{*} \mathrm{C} 30: 0+* \mathrm{C} 30: 1+ \\
{ }^{*} \mathrm{C} 30: 2\end{array}$ & & & & & $128.5 \pm 11.5$ & $12.0 \pm 1.2$ & & \\
\hline Total & $577.8 \pm 1.6$ & & $1820.9 \pm 40.5$ & & $1076.0 \pm 42.9$ & & $2981.6 \pm 247.1$ & \\
\hline \#cells & $3 \times 10^{5}$ & & $3 \times 10^{7}$ & & $3 \times 10^{5}$ & & $3 \times 10^{7}$ & \\
\hline
\end{tabular}

22-dehydrocholesterol $=\Delta 5,22-\mathrm{C} 27: 2 ;$ cholesterol $=\Delta 5-\mathrm{C} 27: 1 ;$ brassicasterol $=\Delta 5,22-\mathrm{C} 28: 2 ;$ desmosterol $=\Delta 5,24-\mathrm{C} 27: 2$; stigmasterol $=\Delta 5,22-\mathrm{C} 29: 2$; ergosterol $=\Delta 5,7,22-\mathrm{C} 28: 3$; fungisterol $=\Delta 7-\mathrm{C} 28: 1$ and 7-dehydroporiferasterol $=\Delta 5,7,22-\mathrm{C} 29: 3$; trace $<$ 20ng. *Sterols are identified with number of carbon atoms and number of double bonds based on molecular mass determined by GC/MS analyses. The number of prey-depleted cells used for sterol analyses was twice the number used in the feeding experiments; 
values presented in the table have been normalized to the number of cells used for inoculations in feeding experiments (Tables 5 and 6). 
Table 3. Sterol composition and content (ng) of Oxyrrhis marina cultures fed Rhodomonas salina; all values are mean \pm SD of 3 replicates, each of which was derived from the pooled lipids of 2 culture bottles.

\begin{tabular}{|c|c|c|c|c|}
\hline Sterols (ng) & $\begin{array}{c}\text { Om-Rs Initial } \\
\text { (Day 0) }\end{array}$ & Om-Rs Day 1 & Om-Rs Day 2 & Om-Rs Day 3 \\
\hline 22-dehydrocholesterol & trace & trace & trace & trace \\
\hline Cholesterol & $115.6 \pm 11.1^{\mathrm{a}}$ & $145.8 \pm 59.5^{\mathrm{a}}$ & $258.1 \pm 27.2^{b}$ & $452.0 \pm 31.5^{c}$ \\
\hline Brassicasterol & $5463.2 \pm 361.6^{\mathrm{c}}$ & $3863.9 \pm 1393.2^{\text {bc }}$ & $2869.6 \pm 159.0^{\mathrm{ab}}$ & $1636.8 \pm 57.3^{\mathrm{a}}$ \\
\hline Total & $5578.7 \pm 368.8^{b}$ & $4009.8 \pm 1452.6^{\mathrm{ab}}$ & $3127.7 \pm 167.7^{\mathrm{a}}$ & $2088.8 \pm 26.2^{\mathrm{a}}$ \\
\hline \# O. marina $\left(\mathrm{x} 10^{5}\right)$ & 3 & $5.5 \pm 1.9$ & $23.10 \pm 0.4$ & $24.5 \pm 0.3$ \\
\hline$\#$ R. salina $\left(\times 10^{5}\right)$ & 300 & $113.2 \pm 49.0$ & -- & -- \\
\hline O. marina $\mu \mathrm{g} \mathrm{C}$ & 101 & $184.0 \pm 62.0$ & $776.0 \pm 15.0$ & $822.0 \pm 8.0$ \\
\hline R. salina $\mu \mathrm{g} \mathrm{C}$ & 1950 & $736.0 \pm 318.0$ & -- & -- \\
\hline Total $\mu g$ C & 2051 & $920.0 \pm 381.0$ & $776.0 \pm 15.0$ & $822.0 \pm 8.0$ \\
\hline
\end{tabular}

All values are mean \pm SD $(n=3)$. Different letters denote significant differences at the $\mathrm{p}<0.05$ level. 22-dehydrocholesterol $=\Delta 5$,22$\mathrm{C} 27: 2$; cholesterol $=\Delta 5 \mathrm{C} 27: 1$ and brassicasterol $=\Delta 5,22-\mathrm{C} 28: 2$; trace $<20 \mathrm{ng}$. 
Table 4. Sterol composition and content (ng) of Gyrodinium dominans cultures fed Rhodomonas salina; all values are mean \pm SD of 3 replicates, each of which was derived from the pooled lipids of 2 culture bottles. .

\begin{tabular}{|c|c|c|c|c|}
\hline Sterols (ng) & $\begin{array}{l}\text { Gd-Rs Initial } \\
\text { (Day 0) }\end{array}$ & Gd-Rs Day 1 & Gd-Rs Day 2 & Gd-Rs Day 4 \\
\hline 22-dehydrocholesterol & $93.9 \pm 4.4^{\mathrm{b}}$ & $87.5 \pm 5.9^{b}$ & $91.8 \pm 6.5^{b}$ & trace $^{a}$ \\
\hline Cholesterol & $77.9 \pm 21.8^{\mathrm{a}}$ & $73.4 \pm 25.9^{\mathrm{a}}$ & $71.9 \pm 19.9^{\mathrm{a}}$ & $1916.6 \pm 702.0^{b}$ \\
\hline Desmosterol & trace & trace & trace & trace \\
\hline Brassicasterol & $8044.2 \pm 105.2^{d}$ & $6919.3 \pm 91.6^{\mathrm{c}}$ & $6149.7 \pm 81.4^{b}$ & $893.4 \pm 101.6^{\mathrm{a}}$ \\
\hline *C29:0 & $104.8 \pm 21.2^{\mathrm{a}}$ & $224.5 \pm 89.4^{\mathrm{a}}$ & $323.4 \pm 166.9^{\mathrm{a}}$ & $823.5 \pm 140.0^{b}$ \\
\hline *C29:1 (a) & $85.6 \pm 7.5^{\mathrm{a}}$ & $357.7 \pm 33.8^{b}$ & $686.1 \pm 35.1^{\mathrm{c}}$ & $1518.7 \pm 89.2^{d}$ \\
\hline *C29:1 (b) & $178.5 \pm 7.0^{\mathrm{a}}$ & $353.1 \pm 11.1^{b}$ & $604.0 \pm 37.0^{\mathrm{c}}$ & $1650.6 \pm 126.5^{c}$ \\
\hline *C29:2 & $64.3 \pm 9.8^{\mathrm{a}}$ & $269.9 \pm 21.3^{b}$ & $454.7 \pm 23.1^{\mathrm{c}}$ & $1975.7 \pm 242.3^{c}$ \\
\hline $\begin{array}{c}* \mathrm{C} 30: 2+* \mathrm{C} 30: 1+ \\
* \mathrm{C} 30: 0\end{array}$ & $48.0 \pm 43.9$ & $252.0 \pm 237.7$ & $435.3 \pm 388.9$ & $900.0 \pm 471.3$ \\
\hline Total & $8674.7 \pm 179.3$ & $8537.5 \pm 296.2$ & $8817.0 \pm 669.2$ & $9678.5 \pm 873.2$ \\
\hline$\# G$. dominans $\left(\mathrm{x} 10^{5}\right)$ & 3 & $4.0 \pm 0.1$ & $6.2 \pm 0.1$ & $23.2 \pm 1.0$ \\
\hline$\#$ R. salina $\left(\mathrm{x} 10^{5}\right)$ & 300 & $204.0 \pm 23.6$ & $190.3 \pm 3.0$ & $14.1 \pm 3.9$ \\
\hline G. dominans $\mu \mathrm{g} \mathrm{C}$ & 85 & $112.0 \pm 3.0$ & $174.0 \pm 3.0$ & $655.0 \pm 28.0$ \\
\hline R. salina $\mu \mathrm{g}$ C & 1950 & $1326.0 \pm 154.0$ & $1237.0 \pm 19.0$ & $92.0 \pm 26.0$ \\
\hline Total $\mu \mathrm{g} \mathrm{C}$ & 2035 & $1438.0 \pm 156.0$ & $1411.0 \pm 22.0$ & $747.0 \pm 53.0$ \\
\hline
\end{tabular}

All values are mean $\pm S D(n=3)$. Different letters denote significant differences at the $\mathrm{p}<0.05$ level. 22-dehydrocholesterol $=\Delta 5$,22$\mathrm{C} 27: 2$; cholesterol $=\Delta 5$-C27:1; brassicasterol $=\Delta 5,22-\mathrm{C} 28: 2$; desmosterol $=\Delta 5,24-\mathrm{C} 27: 2 ;$ trace $<20$ ng. $*$ Sterols are identified with number of carbon atoms and number of double bonds based on molecular mass determined by GC/MS analyses. 
Table 5. Sterol composition and content (ng) of sterols in Oxyrrhis marina cultures fed Dunaliella tertiolecta; all values are mean \pm SD of 3 replicates, each of which is derived from the pooled lipids of 2 culture bottles.

\begin{tabular}{|c|c|c|c|c|}
\hline Sterol (ng) & $\begin{array}{c}\text { Om-Dt Initial } \\
\text { (Day 0) }\end{array}$ & Om-Dt Day 1 & Om-Dt Day 2 & Om-Dt Day 3 \\
\hline 22-dehydrocholesterol & $103.6 \pm 11.2^{\mathrm{a}}$ & $555.9 \pm 59.8^{b}$ & $1934.6 \pm 123.6^{\mathrm{d}}$ & $1220.7 \pm 56.7^{\mathrm{c}}$ \\
\hline Cholesterol & $515.1 \pm 96.8$ & $606.7 \pm 189.1$ & $536.8 \pm 22.6$ & $657.8 \pm 35.4$ \\
\hline Brassicasterol & $87.0 \pm 16.6^{\mathrm{a}}$ & $678.4 \pm 118.8^{\mathrm{c}}$ & $689.8 \pm 28.1^{\mathrm{c}}$ & $355.2 \pm 30.6^{b}$ \\
\hline Stigmasterol & $276.7 \pm 28.9^{\mathrm{c}}$ & $316.9 \pm 18.8^{d}$ & $174.9 \pm 20.5^{b}$ & $120.9 \pm 3.8^{a}$ \\
\hline Ergosterol & $1085.0 \pm 154.2^{b}$ & $947.3 \pm 45.8^{b}$ & $630.9 \pm 51.0^{a}$ & $499.7 \pm 19.1^{\mathrm{a}}$ \\
\hline Fungisterol & $542.3 \pm 126.5^{b}$ & $453.8 \pm 118.6^{b}$ & $92.1 \pm 18.2^{\mathrm{a}}$ & trace $^{\mathrm{a}}$ \\
\hline 7-dehydroporiferasterol & $773.5 \pm 190.7^{b}$ & $500.8 \pm 110.3^{b}$ & trace $^{\mathrm{a}}$ & trace $^{\mathrm{a}}$ \\
\hline Total & $3383.1 \pm 168.3^{b}$ & $4059.9 \pm 114.4^{c}$ & $4059.0 \pm 208.5^{c}$ & $2854.4 \pm 66.9^{\mathrm{a}}$ \\
\hline \#O. marina $\left(\mathrm{x} 10^{5}\right)$ & 3 & $6.8 \pm 0.0$ & $16.4 \pm 0.4$ & $16.6 \pm 1.0$ \\
\hline$\#$ D. tertiolecta $\left(\times 10^{5}\right)$ & 300 & $32.7 \pm 2.7$ & - & - \\
\hline O. marina $\mu \mathrm{g} \mathrm{C}$ & 101 & $230.0 \pm 1.0$ & $550.0 \pm 13.0$ & $558.0 \pm 34.0$ \\
\hline D. tertiolecta $\mu \mathrm{g} \mathrm{C}$ & 1158 & $126.0 \pm 10.0$ & & \\
\hline Total $\mu \mathrm{g}$ C & 1259 & $356.0 \pm 12.0$ & $550.0 \pm 13.0$ & $558.0 \pm 34.0$ \\
\hline
\end{tabular}

All values are mean $\pm \mathrm{SD}(\mathrm{n}=3)$. Different letters denote significant differences at the $\mathrm{p}<0.05$ level. 22-dehydrocholesterol $=\Delta 5$,22$\mathrm{C} 27: 2$; cholesterol $=\Delta 5$-C27:1; brassicasterol $=\Delta 5,22-\mathrm{C} 28: 2$; ergosterol $=\Delta 5,7,22-\mathrm{C} 28$ :3; fungisterol $=\Delta 7-\mathrm{C} 28: 1$; stigmasterol $=$ $\Delta 5,22-\mathrm{C} 29: 2$ and 7-dehydroporiferasterol $=\Delta 5,7,22-\mathrm{C} 29: 3$; trace $<20 \mathrm{ng}$. 
Table 6. Sterol composition and content (ng) of Gyrodinium dominans cultures fed Dunaliella tertiolecta; all values are mean \pm SD of 3 replicates, each of which is derived from the pooled lipids of 2 culture bottles. .

\begin{tabular}{|c|c|c|c|c|}
\hline Sterols (ng) & $\begin{array}{c}\begin{array}{c}\text { Gd-Dt Initial } \\
\text { (Day 0) }\end{array} \\
\end{array}$ & Gd-Dt Day 1 & Gd-Dt Day 2 & Gd-Dt Day 4 \\
\hline 22-dehydrocholesterol & $33.0 \pm 57.2$ & $154.2 \pm 138.7$ & $148.0 \pm 24.7$ & $115.8 \pm 84.6$ \\
\hline Cholesterol & $85.0 \pm 23.3^{a}$ & $978.6 \pm 155.7^{b}$ & $113.4 \pm 36.3^{\mathrm{a}}$ & $892.7 \pm 121.2^{b}$ \\
\hline Desmosterol & trace & trace & trace & trace \\
\hline Brassicasterol & $135.0 \pm 38.4^{\mathrm{a}}$ & $141.0 \pm 126.8^{\mathrm{a}}$ & $519.6 \pm 235.2^{b}$ & $695.3 \pm 87.9^{b}$ \\
\hline Stigmasterol & trace & trace & trace & trace \\
\hline Ergosterol & $1064.5 \pm 155.5^{b}$ & $439.6 \pm 91.4^{\mathrm{a}}$ & $344.4 \pm 133.9^{\mathrm{a}}$ & $503.7 \pm 20.5^{\mathrm{a}}$ \\
\hline Fungisterol & $359.5 \pm 67.0^{\mathrm{a}}$ & $694.5 \pm 139.3^{b}$ & $394.4 \pm 128.7^{\mathrm{a}}$ & $539.7 \pm 105.5^{\mathrm{ab}}$ \\
\hline 7-dehydroporiferasterol & $910.3 \pm 45.2$ & $683.7 \pm 242.9$ & $576.6 \pm 109.9$ & $918.8 \pm 56.7$ \\
\hline$*_{\mathrm{C} 2} 29: 0$ & $157.7 \pm 68.4^{\mathrm{a}}$ & $436.7 \pm 21.1^{b}$ & $507.4 \pm 97.9^{b}$ & $1304.7 \pm 119.1^{c}$ \\
\hline${ }^{*} \mathrm{C} 29: 1 \mathrm{a}$ & $338.1 \pm 243.9^{a}$ & $609.3 \pm 111.8^{a b}$ & $671.4 \pm 162.3^{\mathrm{ab}}$ & $937.3 \pm 29.9^{\mathrm{b}}$ \\
\hline${ }^{*} \mathrm{C} 29: 1 \mathrm{~b}$ & $661.2 \pm 18.4^{\mathrm{a}}$ & $739.9 \pm 69.7^{\mathrm{a}}$ & $730.1 \pm 220.6^{\mathrm{a}}$ & $1074.1 \pm 100.9^{b}$ \\
\hline *C29:2 & $166.6 \pm 144.7^{\mathrm{a}}$ & $524.0 \pm 50.7^{\mathrm{a}}$ & $457.3 \pm 140.4^{\mathrm{a}}$ & $1779.6 \pm 203.6^{b}$ \\
\hline $\begin{array}{c}{ }^{*} \mathrm{C} 30: 2+* \mathrm{C} 30: 1+ \\
{ }^{*} \mathrm{C} 30: 0\end{array}$ & $284.0 \pm 40.9^{\mathrm{a}}$ & $471.6 \pm 141.8^{\mathrm{ab}}$ & $311.9 \pm 75.1^{\mathrm{a}}$ & $688.9 \pm 185.3^{b}$ \\
\hline Total & $4194.3 \pm 665.9^{a}$ & $5873.1 \pm 1016.2^{a}$ & $4774.5 \pm 1236.6^{a}$ & $9450.5 \pm 390.3^{b}$ \\
\hline $\begin{array}{l}\# G \text {. dominans }\left(\times 10^{5}\right) \\
\# D . \text { tertiolecta }\left(\times 10^{5}\right)\end{array}$ & $\begin{array}{c}3 \\
300\end{array}$ & $\begin{array}{c}4.3 \pm 1.5 \\
298.0 \pm 9.0\end{array}$ & $\begin{array}{c}7.0 \pm 0.2 \\
249.1 \pm 2.5\end{array}$ & $\begin{array}{c}13.2 \pm 0.8 \\
60.0 \pm 12.6\end{array}$ \\
\hline G. dominans $\mu \mathrm{g} \mathrm{C}$ & 85 & $120.0 \pm 42.0$ & $198.0 \pm 4.0$ & $372.0 \pm 20.0$ \\
\hline D. tertiolecta $\mu \mathrm{g} \mathrm{C}$ & 1158 & $1150.0 \pm 34.0$ & $962.0 \pm 10.0$ & $231.0 \pm 49.0$ \\
\hline Total $\mu \mathrm{g}$ C & 1242.8 & $1270.0 \pm 76.0$ & $1159.0 \pm 7.0$ & $604.0 \pm 51.0$ \\
\hline
\end{tabular}


All values are mean $\pm \mathrm{SD}(\mathrm{n}=3)$. Different letters denote significant differences at the $\mathrm{p}<0.05$ level. Gd $=$ Gyrodinium dominans; $\mathrm{Dt}$ $=$ Dunaliella tertiolecta; 22-dehydrocholesterol $=\Delta 5,22-\mathrm{C} 27: 2$; cholesterol $=\Delta 5-\mathrm{C} 27: 1 ;$ brassicasterol $=\Delta 5,22-\mathrm{C} 28: 2 ;$ desmosterol $=$ $\Delta 5,24-\mathrm{C} 27: 2$; stigmasterol= $\Delta 5,22-\mathrm{C} 29: 2$; ergosterol $=\Delta 5,7,22-\mathrm{C} 28$ :3; fungisterol $=\Delta 7$-C28:1 and 7-dehydroporiferasterol $=\Delta 5,7,22-$ C29:3; trace $<20$ ng. *Sterols are identified with number of carbon atoms and number of double bonds based on molecular mass determined by GC/MS analyses. 
Table 7. Cholesterol production (ng per mg algal C consumed; Mean $\pm \mathrm{SD}, \mathrm{n}=3$ ) of $G$. dominans (Gd) at Day 4 and $O$. marina $(\mathrm{Om})$ at Day 3 after feeding $R$. salina (Rs) or $D$. tertiolecta (Dt) and cholesterol content in their algal preys, $R$. salina and $D$. tertiolecta. All values are mean \pm SD of 3 replicates.

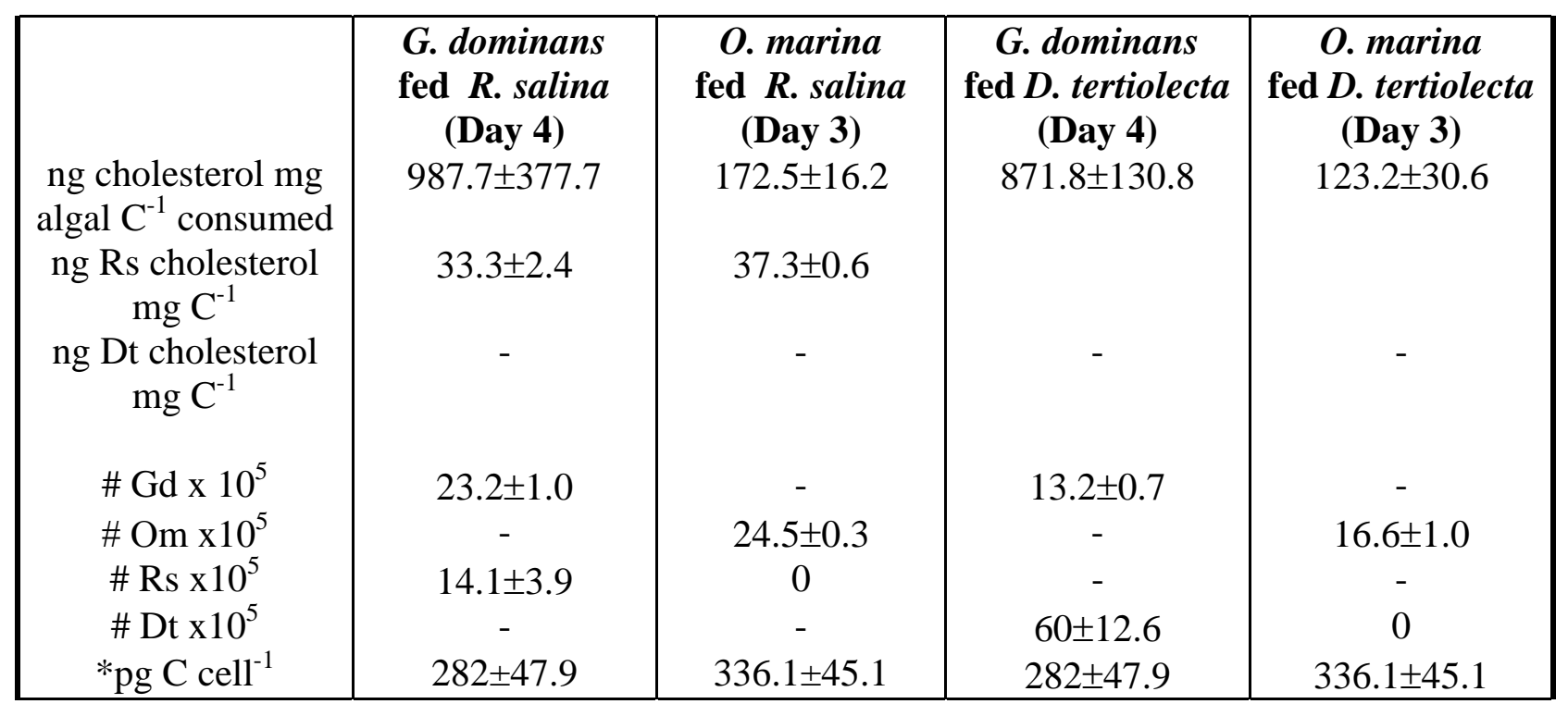

* Chu et al. 2008. 


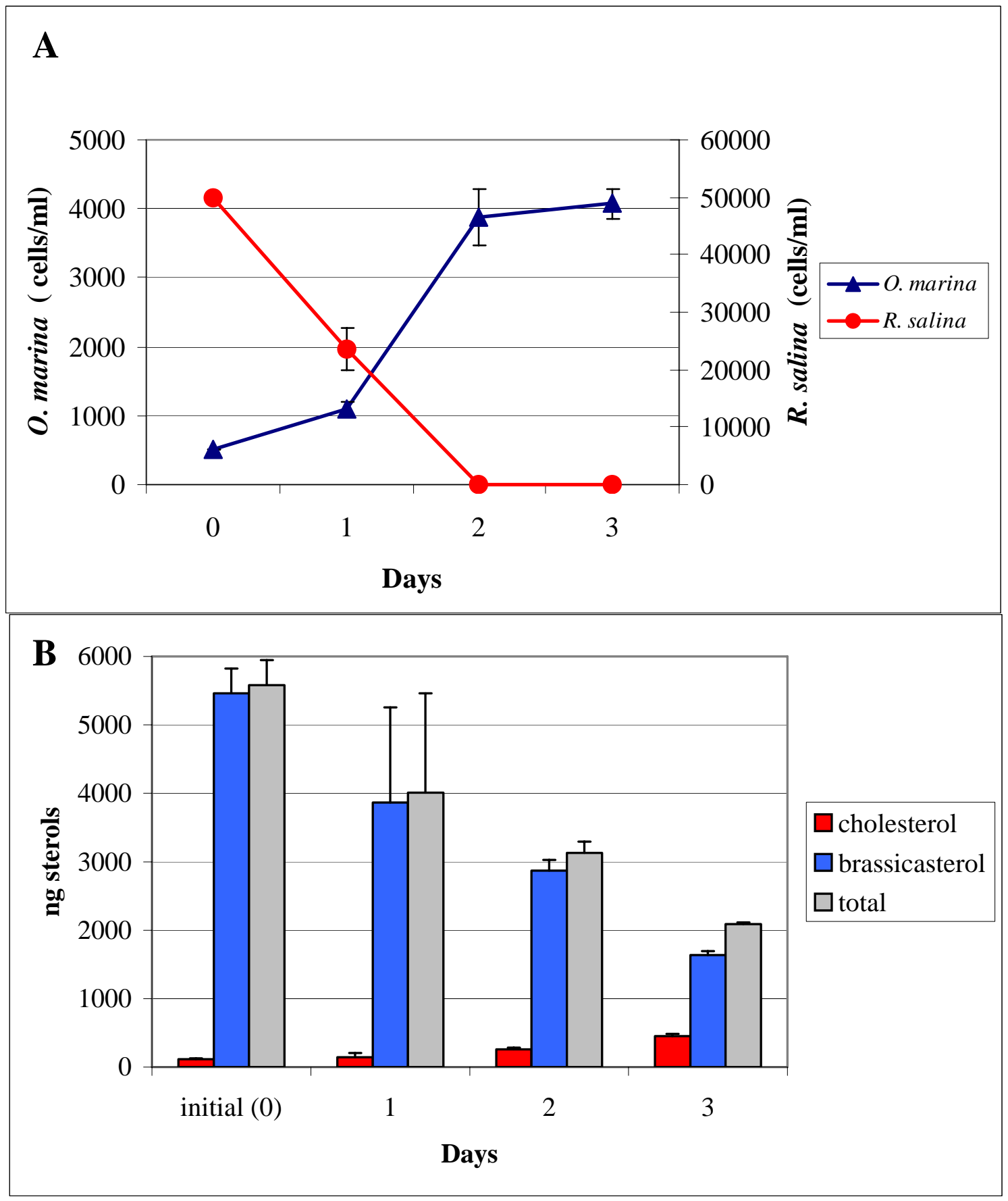

Figure2: (A) Predator-prey dynamic of Oxyrrhis marina fed Rhodomonas salina ( $\mathrm{n}=6$ bottles of cultures at each sampling date); (B) Changes of sterol profile and content in Oxyrrhis marina fed Rhodomonas salina. All values are mean \pm SD of 3 replicates, each of which is derived from the pooled lipids of 2 culture bottles. . 

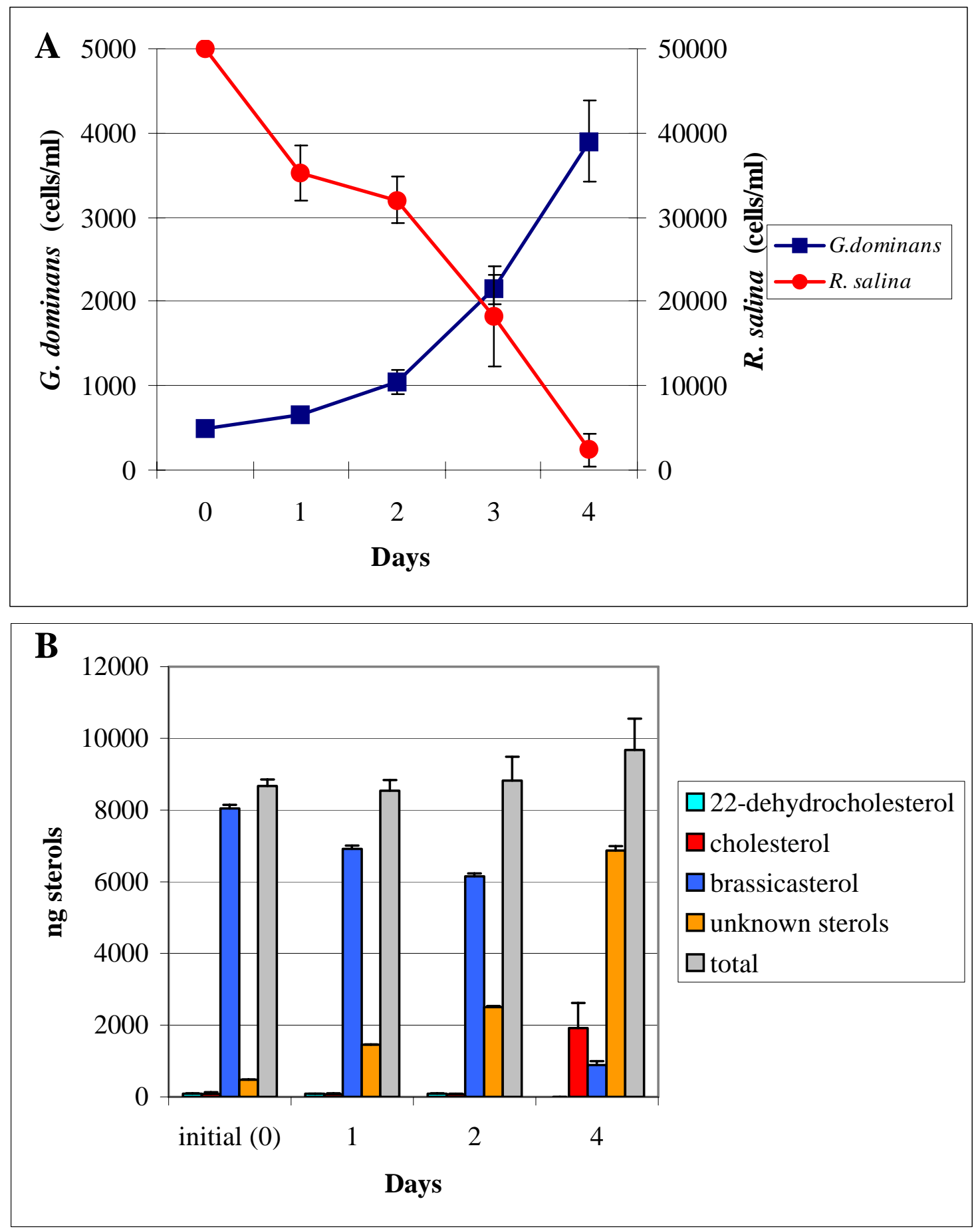

Figure 3: (A) Predator-prey dynamic of Gyrodinium dominans fed Rhodomonas salina ( $\mathrm{n}=6$ bottles of cultures at each sampling date); (B) Changes of sterol profile and content in Gyrodinium dominans fed Rhodomonas salina. All values are mean \pm SD of 3 replicates, each of which is derived from the pooled lipids of 2 culture bottles. Unknown sterols: sum of 29:0, 29:1a, 29:1b, 29:2, 30:0, 30:1 and 30:2. 

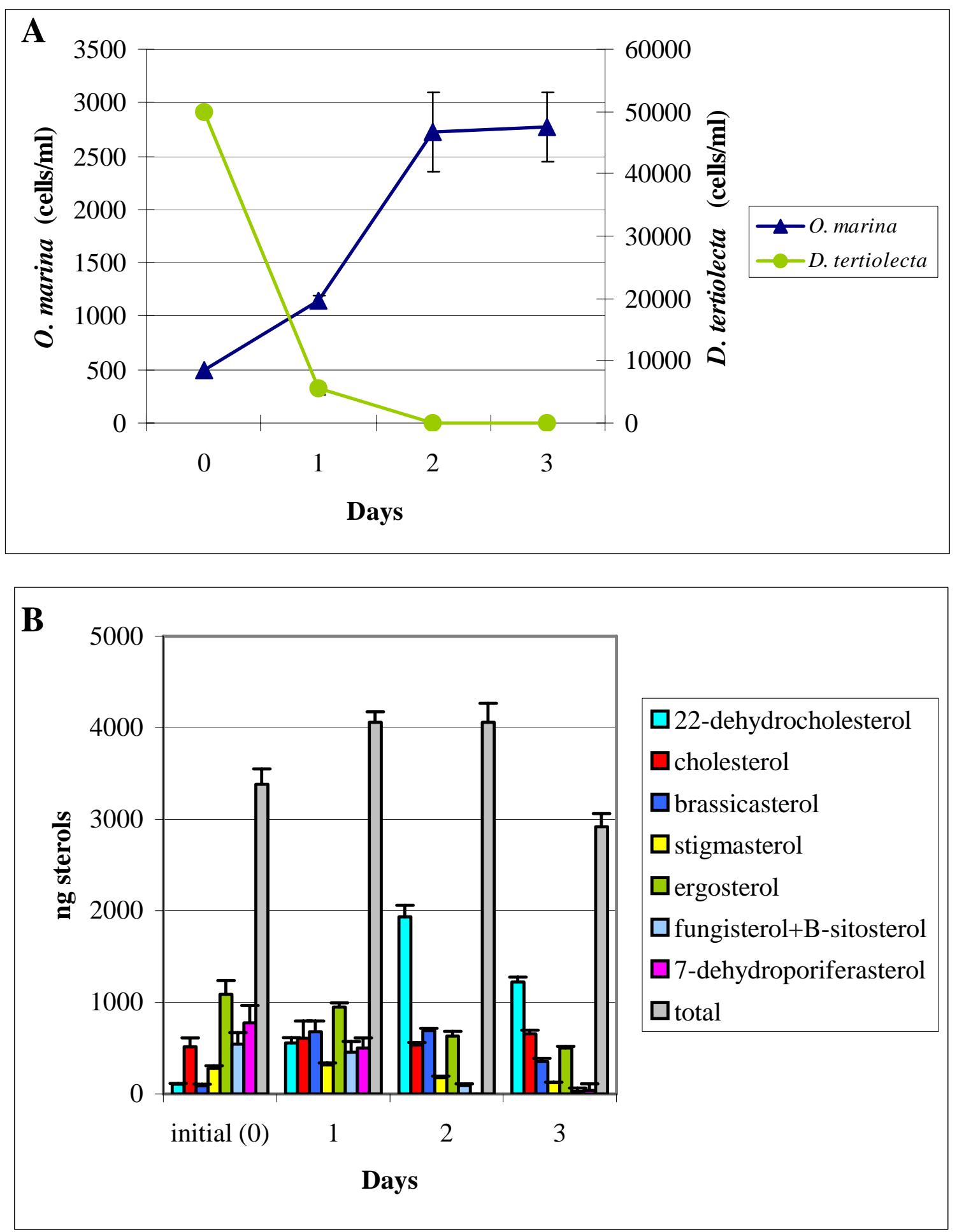

Figure 4: (A) Predator-prey dynamic of Oxyrrhis marina fed Dunaliella tertiolecta $(\mathrm{n}=6$ bottles of cultures at each sampling date); (B) Changes of sterol profile and content in Oxyrrhis marina fed Dunaliella tertiolecta. All values are mean \pm SD of 3 replicates, each of which is derived from the pooled lipids of 2 culture bottles. 

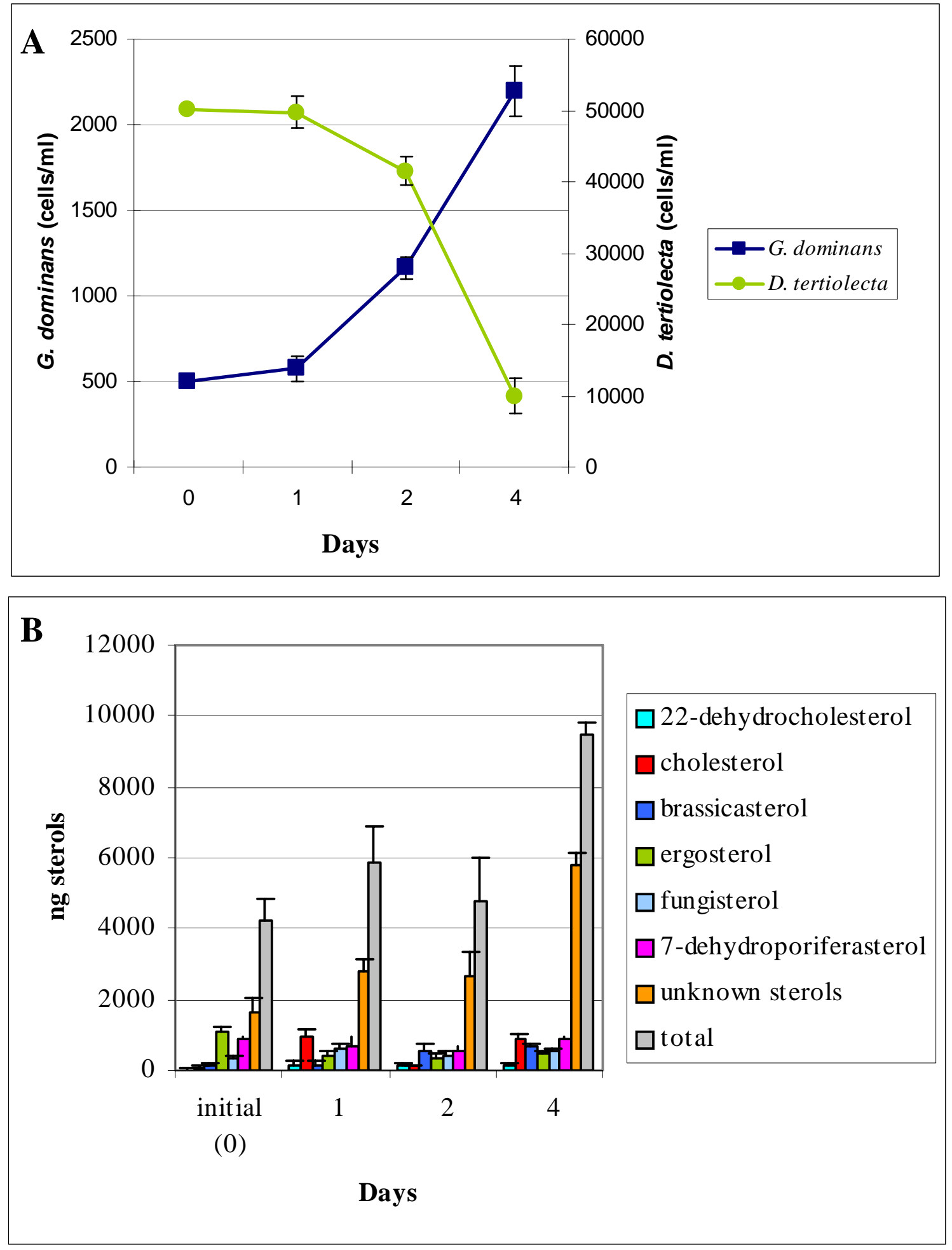

Figure 5: (A) Predator-prey dynamic of Gyrodinium dominans fed Dunaliella tertiolecta ( $n=6$ bottles of cultures at each sampling date); (B) Changes of sterol profile and content 
in Gyrodinium dominans fed Dunaliella tertiolecta. All values are mean \pm SD of 3 replicates, each of which is derived from the pooled lipids of 2 culture bottles.

Unknown sterols: sum of 29:0, 29:1a, 29:1b, 29:2, 30:0, 30:1 and 30:2. 